\title{
Reconceptualizing Criminal Law Defenses
}

Victoria Nourse

Georgetown Law Center, vfn@law.georgetown.edu

Georgetown Public Law and Legal Theory Research Paper No. 12-098

This paper can be downloaded free of charge from:

https://scholarship.law.georgetown.edu/facpub/992

http://ssrn.com/abstract=2113696

151 U. Pa. L. Rev. 1691-1746 (2003)

This open-access article is brought to you by the Georgetown Law Library. Posted with permission of the author. Follow this and additional works at: https://scholarship.law.georgetown.edu/facpub

Part of the Criminal Law Commons, Criminal Procedure Commons, Legal History Commons, Legal Writing and Research Commons, Political Theory Commons, and the Public Law and Legal Theory Commons 


\title{
RECONCEPTUALIZING CRIMINAL LAW DEFENSES
}

\begin{abstract}
V.F. NOURSE ${ }^{\dagger}$
In 1933, one of the leading theorists of the criminal law, Jerome Michael, wrote openly of the criminal law "as an instrument of the state." Today, criminal law is largely allergic to claims of political theory; commentators obsess about theories of deterrence and retribution, and the technical details of model codes and sentencing grids, but rarely speak of institutional effects or political commitments. In this Article, I aim to change that emphasis and to examine the criminal law as a tool for governance. My approach is explicitly constructive: it accepts the criminal law that we have, places it in a counterfactual perspective, and asks what this means for institutional arrangements-our relations to each other and to the state. This focus is then applied to reconceptualize a variety of criminal law defenses, ranging from self-defense and insanity to necessity and provocation. In the analysis of these doctrines, I argue that defenses cannot be fully explained by the standard inquiry into individual minds, characters, or virtues. Instead, defenses reflect the need for a liberal polity to control vengeance. I go on to argue that the standard view may yield a "paradox" of individualization which, in some cases, may actually work to the detriment of individuals. To undertake this kind of inquiry invites particular avenues of inquiry in the criminal law that have never received enough support, such as history and comparative law; and provides a new perspective on a variety of theoretical developments of the past decade, including the collapse of the harm principle, the increasing importance of social norm scholarship, and the impact of feminism on the substantive criminal lazu.
\end{abstract}

${ }^{\dagger}$ Visiting Professor of Law, Yale Law School (Fall 2002); Visiting Professor of Law, New York University School of Law (Spring 2003); Professor of Law, University of Wisconsin Law School. I have many to thank for their helpful comments on this Article, which was presented at workshops at New York University School of Law, the University of Wisconsin Law School, DePaul University Law School, and Brooklyn Law School. Thanks to Ann Althouse, Mary Becker, Jane Schacter, David Schwartz, and Kate Stith for reading this Article. My temporary colleagues at Yale, Dan Kahan and Scott Shapiro, deserve special mention for their attention to, and arguments about, this Article at the close of a very busy term; Kenji Yoshino provided insight into questions of implantation of institutional effects into individual minds, and Bob Ellickson made me think harder about governance and crime. At NYU, special thanks for insightful questions and comments by Steve Schulhofer, David Garland, Vicki Been, Daryl Levinson, Barry Friedman, and Jerome Bruner. Finally, Meredith Earley contributed extraordinary research assistance. And, as always, none of this could have happened without my family who, this year, has endured quite a bit more than most families would ever tolerate; I do not write for Rick, Mia, and Jack but because of their extraordinary support.

'Jerome Michael \& Mortimer J. Adler, Crime, Law \& Social Science 342-43 (1933). 


\section{INTRODUCTION}

It is occasionally confessed that "the doctrines of substantive criminal law have [little] to do with the causes or prevention of criminal behavior." If there is any truth to this, then a rather large question is left looming: What does explain the criminal law? Deterrence and retribution, the twin pillars of much criminal law theory, too often disappoint. Think about it for a moment: if we truly wanted to deter more crime, or exercise our vengeance to its utmost, we would "string 'em up," kill the offender's children, or jail the innocent. We don't do these things-not necessarily because of deterrence or retribution (whatever these otherwise capacious ideas mean) ${ }^{3}$ but because the resulting political order would be intolerable."

We know that dictatorships deal with crime very easily. We also know that they seek to legitimize their violence through the criminal law. Hitler's criminal code formed mens rea and actus reus in the image of the Volk; Stalin's code formed these same ideas in terms of Bolshevik ideology." Today, the new Chinese criminal code purports to limit criminalization to the "harm" principle," but then defines harm in ways that enable the punishment of dissent. ${ }^{7}$ Now think about why our criminal law may look as it does. Perhaps we have forgotten to ask

2 Foundations of Criminal Law 6 (Leo Katz et al. eds., 1999).

"On the various cultural meanings of deterrence, see Dan Kahan, The Secrel Ambilion of Deterrence, 113 HARV. L. REV. 413, 415 (1999), which details the expressive content of deterrence arguments. For a survey of various forms of retribution arguments, see FOUNDATIONS OF CRIMINAL L.AW, supra note 2, at 48-154 (1999).

"For some, this will seem obvious; for others, controversial. Some believe, for example, that a mixed theory of deterrence limited by retributive aims may suffice to avoid at least some of the possibilities I have outlined above. See, e.g., H.L.A. HART, Punishimen't ANd ResponsibILITy: EsSAYs IN THE PHILOSOl'Hy OF L.AW 8-12 (1968) (arguing, famously, that retribution is not a "justifying" but a "distributive" aim of punishment, limiting the distribution of punishment to particular persons). Retribution as wrongdoing-specific (as limiting distribution) does not necessarily prohibit a state from wreaking vengeance on particular political enemies or particular races if the relevant society believes that the political or racial opposition is committing a grave wrong.

"Contrary to popular imagination, both Hitler and Stalin spent an enormous amount of time on criminal codes that otherwise sought to legitimize the violence of the state. On specific doctrines, see infra notes 31-32.

i John Stuart Mill, On Liberiy 13 (Stefan Collini ed., Cambridge Univ. Press 1989) (1859).

7 Compare Mi Zhou \& Shizhou Wang, China, [2 Crim. L.] Int'l Encyclopedia L. (Kluwer Law Int'l) para. 27 (Jan. 2001) ("Fundamentally, a criminal offence should be harmful to society. Without social harmfulness, no conduct can be deemed a crime."), with id. para. 26 (defining a criminal offense as anything that "subverts the state power of the people's democratic dictatorship and overthrows the socialist state"). 
whether our criminal law both reflects and helps to construct our own liberal political order.

Some intellectual grounding for this hypothesis can be obtained from John Rawls's famous essay, Two Concepts of Rules." Although the essay is known for other reasons, it makes a very important argument about the nature of punishment as an institution. Rawls argues that the standard tools of punishment discourse-retribution and deterrence - - tend to reflect unstated institutional assumptions: utilitarian arguments tend to favor the ideal of the legislator who looks to the future, general needs of the polity; retributive views, by contrast, tend to assume a judicial and retrospective approach focusing on individualized justice. ${ }^{10}$ To dramatize the importance of these institutional assumptions and effects, Rawls imagines a rule of individual moral atrocity (punishment of the innocent) and considers its institutional implications (the imaginary system created is dubbed "telishment")."

The point of the telishment example is to show that rules appearing to aim at individuals may also transform the practice of punishment, changing the nature of the offices and roles of those who govern." As Rawls puts it, "[o]nce one realizes that one is involved in setting up an institution, one sees that the hazards are very great." There follows, in this essay, a list of questions about the design of the institution of punishment and the conduct of officials-whether and

${ }^{8}$ JOHN RAWLS, Tivo Concepls of Rules, in COllected PAPERS 20 (Samuel Freeman ed., 1999).

"Rawls suggests that these concepts are, among other things, crude projections of institutional identities and roles. See id. at 23-24 (" $[\mathrm{O}]$ ne notes that the different sorts of considerations which would ustally be offered as reasons for what is done under the cover of these offices can be paired off with the competing justifications of punishment [retribution and deterrence].").

10 Id. at 23.

11 Rawls also stated:

Once this is understood it is clear what the countermove to Carritt's argument [about punishing the innocent] is. One must describe more carefully what the institution is which his example suggests, and then ask oneself whether or not it is likely that having this institution would be for the benefit of society in the long run. One must not content oneself with the vague thought that, when it's a question of this case, it would be a good thing if somebody did something even if an innocent person were to suffer.

Id. at 27 (emphasis omitted).

${ }^{12}$ Id. at 23. It follows that Rawls would disagree with Hart that many of the seemingly "individualized" features of the criminal law are necessarily "exceptions" to the general social welfare. He likely would be committed to the position that the "individualizing" features also serve institutionalized (or generalized) ends.

${ }^{13}$ ld. at 27 (emphasis omitted). 
how, in a system of telishment, we are ever to know whether these officials are "authorized" to issue a "telishment" or systematically "deceptive" about telishment. ${ }^{14}$ Put in other words, once one punishes the innocent, one not only harms the individual punished but also creates collateral effects for the law-abiding and for those who govern the practice of punishment.

The logic of this claim parallels the insights of other disciplines, such as law and economics, which insist that to understand the effect of a law, one cannot simply look at the law itself. ${ }^{15}$ One must look, as well, to "how people will respond" to the law and what relations they will create in response." Rawls is looking at the institutional and political (rather than market/contract) effects of individualized rules and arguing that one cannot understand an individualized rule (punishing an innocent man) without considering important responses to, or effects of, the rule on (1) law-abiding citizens; (2) legal officials; and (3) the relations created between them. Just as a rule that punishes speech is likely to have "chilling" effects (all law-abiding speakers respond to the rule), the practice of telishment not only causes harm to the individual thrown in jail but inspires widespread fear in the populace about "whether the same fate won't at any time fall on them." ${ }^{\prime 7}$ The rule also has effects on the relation between citizens and their government; a law that gives officers discretion and opportunities for deception in the determination of "who" is innocent is likely to yield widespread distrust in government officials. In such a world, the "people will come to have a very different attitude towards" tice of punishment and, I would add, their government as a whole.

The risks of which Rawls speaks are what we might call risks to a political order or claims of political structure." This insight invites

${ }^{14}$ See id. at 27 ("For example, what check is there on officials? How is one to tell whether or not the actions are authorized? How is one to limit the risks involved in allowing such systematic deception?").

15. See Jennifer Arlen, Comment: The Future of Behavioral Economic Analysis of Law, 51 VAND. L. REV. 1765, 1765-66 (1998) (describing this as the "central contribution of Ronald Coase's pathbreaking article" (citing R.H. Coase, The Problem of Social Cost, 3 J.L. \& ECON. $1(1960))$ ).

16) Id.

17 RAWLS, supra note 8, at 28. Essentially, a rule of liability that focuses on individual wrongs not only protects the individual but, correspondingly, limits the discretion and potential for fratud and overreaching of institutions.

is $I$. .

19. Consider, in particular, Rawls's references to "legislation" and "adjudication":

One can say, then, that the judge and the legislator stand in different posi-

tions and look in different directions: one to the past, the other to the future. 
important questions about modern views of the criminal law. Since the $1970 \mathrm{~s}$, there has been an often unstated consensus that the proper level of analysis of the criminal law is at the individualized level of mind or conduct (whether of individual defendants or the collective sum of all potential defendants). Moreover, it has been assumed that the "individual level" forms an "exception to" and is "opposed to," rather than "constructive of," more generalized rules and institutional commitments. Thus, H.L.A. Hart famously contended that excuses were the individualizing price that a social system of crime control had to pay to protect the "choosing self." But if punishment is seen as a practice, if criminal laws have collateral institutional effects, then perhaps defenses do not represent a price at all, instead serving important purposes not only for defendants but for the law-abiding majority. Indeed, this might explain how, in a world of "tough on crime" politics, we have any defenses as all.

In this Article, I accept Rawls's invitation to consider punishment as an institution. In Part I, I tease out of the criminal law a latent political economy-a set of relations implicit, yet unexpressed, in conventional criminal law theory and public discourse about the criminal law. Using the perspective generated by counterfactual method," I argue that doctrines that have traditionally been thought to focus only

The justification of what the judge does, qua judge, sounds like the retributive view; the justification of what the (ideal) legislator does, qua legislator, sounds like the utilitarian view ... . [T] hese views apply to persons holding different offices with different duties, and situated differently with respect to the system of rules that make up the criminal law. Id. at 23 .

20 HART, supra note 4, at 17-24. Hart, of course, recognizes that there is a systemic element here; what Rawls appears to dispute is that individualizing features necessarily negate the claims of society (or political institutions) rather than being potentially consistent with them.

${ }^{21}$ My method here, as elsewhere, see, e.g., V.F. Nourse, A Popular Consitutional Anatomy: Toward a New View of the Separation of Powers and Federalism, 56 STAN. L. REV. (forthcoming 2003), is counterfactual, by which I engage in thought experiments which isolate particular forms of legal rules or doctrine to consider their "constructive" effects. This follows the literature in the social sciences and, in particular, in international relations, which has recently focused on counterfactual method as a way to test a causal proposition. See, e.g., Richard N. Lebow, What's So Different About a Counterfactual?, 52 WORLD POL. 550, 581-84 (2000) (proposing eight criteria that are appropriate to plausible-world counterfactuals in social science); Robert N. Strassfeld, If . . : Counterfactuals in Latw, 60 GEO. WASH. L. REV. 339, 365-68 (1992) (discussing the use of counterfactuals relating to laws concerning human reactions and behavior). It is also Rawls's method when he constructs the "telishment" institution as a means to explore the embedded institutional commitments of what we call punishment. See RAWLS, supra note 8, at 27 (defining the institution of "telishment"). 
on defendants may actually reflect less about the hearts and minds of defendants than about the needs of the law-abiding and their perceived relation to their government. In Part II, I apply this approach in a place where its application might seem unexpected-to a variety of criminal law defenses, including self-defense, necessity, provocation, and insanity. I urge, in each case, that these defenses incorporate elements that demand deference to majoritarian norms and aim to prevent private punishment. ${ }^{22}$ Put in other words, as Émile Durkheim posited so long ago, the criminal law is not constructed for defendants, it is constructed for the law-abiding. ${ }^{23}$

In Part III, I respond to potential objections to this approach that argue it is illiberal because it looks beyond individual minds or characters or "choosing selves." I claim that, in its crudest forms, an analysis that is conducted solely at the individualized level may backfire; it may actually undermine a liberal polity's own stated aim to respect the individual. Efforts to intellectually sequester the defendant from the state yield a "paradox of individualization" in which state oppression may thrive, implanted by the law into descriptions of persons' minds and actions. ${ }^{24}$ If criminal law theorists are looking for a liberal political theory that can help explain the criminal law, they would be better advised to consider the institutional implications of what Stephen Holmes has called the "anti-self-exemption" principle." Finally, in

"2: As Jerome Bruner has put it, in a democracy, the law symbolizes a "successful struggle against tyranny and autocratic arbitrariness"; and this is nowhere more true than in the criminal law's aim, as rellected in its most particular doctrines, "to stem cycles of revenge." JEROME BRUNER, MAKING STORIES: I_AW, LITERATURE, LIFE 45-46 (2002).

On Durkheim, see DAVId Garland, Punishment and MOdERn SOCIETy 74-76 (1990), which describes Durkheim's reversal of "our usual understanding of the target population of penal measures" as having achieved "canonical" status in the "sociological world." I differ, of course, from a sociological analysis, and Durkheim's own, by arguing here that the criminal law reflects not emotional solidarity but tenets of a political solidarity.

24 This argument, as one will see, bears a strong resemblance to a Foucauldian critique. I have chosen not to emphasize this intellectual connection because of the common assumption that Foucault's ideas are invariably hostile to liberal governance. For a different view, see Andrew Barry et al., Introduction to FOUCAULT AND POLITICAL REASON: LIBERALISM, NEO-LIBERALISM AND RATIONALITIES OF GOVERNMENT 1, 7-12 (Andrew Barry et al. eds., 1996) (reconsidering Foucault's views and liberalism).

2.5 See STEPHEN Holmes, THE ANATOMY OF ANTILIBERALISM 238 (1993) (arguing that "hyperindividual [ism] . . . is explicitly ruled out by the strong norm at the heart of liberal morality: the self-exemption prohibition" (emphasis omitted)); see also infra text accompanying notes $190-95$ (using this principle to define a liberal position that rejects exemptions that prefer one group to another, thus reinforcing the superiority of that group). 
Part IV, I sketch out some implications for this "collateral effects" approach toward the substantive criminal law, hoping to show how it may help us understand apparently anomalous theoretical developments in the criminal law, such as feminism's successes, the harm principle's demise, and the recent turn toward social norms.

\section{The Criminal LaW and Governance}

Imagine a world in which there were no criminal laws. If one assumes a society of persons of different strengths and a certain level of natural aggression, then it is fairly easy to imagine a rather nasty and brutish gathering, one that is "ruled by the strong." It also seems clear that, when we replace our Hobbesian "rule of the strong" with a "rule of law," we must beware that we may reinvent the same "rule of the strong." (After all, without state legitimization, an arrest is no different from a kidnapping.) It is in this sense that the criminal law implies institutions of governance; it reflects an aspiration toward a nonviolent ordering of society that controls both the individual and the state.

At least in theory, then, the criminal law should be seen as a fundamental agent in maintaining a just relation between citizen and state. Although this premise is widely accepted by rather ancient political philosophers, ${ }^{27}$ one is unlikely to read about it in much contemporary scholarship on the criminal law or political theory. Indeed, as George Fletcher has commented, "Criminal punishment is the most

"Si Se ThOMAS HobBes, LeviaTHAN ch. XIII, para. 9 (A.P. Martinich ed., Broadview Press 2002) (1651) (describing life in this type of world as "solitary, poor, nasty, brutish, and short").

${ }^{27}$ See infra notes 175-84 and accompanying text (discussing Locke's view in particular); ChaRLES DE SECONDAT BARON DE MONTESQUIEU, THE SPIRIT OF LAWS, bk. III, ch. 5 (Prometheus Books 2002) (1748) ("Now in republics private crimes are more public, that is, they attack the constitution more than they do individuals ...."). It is also worthwhile noting that the state's role in the criminal law appears as an elementary jurisprudential proposition. As one introductory text explains:

The state is the complaining party in a criminal action . . . and in a sense views itself as the injured party. Thus unlike the case in private or civil actions... the concern of the state is not to address injuries to individuals per se but only to address such injuries to the degree that they also constitute attacks against the state.

JefFrie G. Murphy \& Jules L. Coleman, Philosophy of LAW 114 (rev. ed. 1990). The role of political norms and institutions is also a staple of social theory. See, e.g., GARLAND, supra note 23, at 257 ("[T]O represent the business of punishment ... and to organize penal practices accordingly, promotes a particular image of the state and of its authority, and of its relationship to offenders and other citizens."). 
elementary and obvious expression of the state's sovereign power. . . In the contemporary writing on political theory, however, both criminal law and criminal procedure receive short shrift." 28 This gap is particularly acute for the standard criminal law scholar who, when not busy trying to "solve" the crime problem or deciphering sentencing grids, tends to imagine the criminal law in opposition to, rather than constructive of, a political order.

If the conventional wisdom disappoints, life and history do not. ${ }^{30}$ At some level, we recognize that the criminal law and political life are not unrelated. We see the name of the State in case captions. And we

${ }^{28}$ George P. Fletcher, The Fall and Rise of Criminal Theory, I BUFr. CRIM. I. REV. 275,287 (1998) (noting an "omission" in the literature on criminal law to explore the connections between criminal law and political philosophy).

${ }^{29}$ There are, of course, recent and important efforts to place the criminal law within political context. See KATE STITH \& JOSÉ A. CABranes, FEAR of JUdGing: SENTENCING GUIDELINES IN THE FEDERAL. COURTS 9-38 (1998) (discussing the political history of the sentencing commission); Kahan, supra note 3, at 419-35 (discussing theories of punishment and how they relate to political conflict); William J. Stuntz, The Pathological Politics of Criminal Latu, 100 MiCl. L. REv. 505, 512-19 (2001) (discussing the political incentives to consistently expand the scope of the criminal law). Political theory has figured occasionally in the work of philosophers. See, e.g., MURPHY \& COLEMAN, supma note 27, at 109-37 (analyring the problem of criminalization and punishment within the context of social and political philosophy); Benjamin C. Zipursky, Self-Defense, Domination, and the Social Contrat, 57 U. PITT. L. REv. 579, 613-14 (1996) (seeking to reconcile the apparent conflict within political theory between liberal political philosophy and dominance theory in feminism). Still, political theory has received little sustained attention among standard criminal law scholars. For a recent and impressive defense of the political theory perspective, see Guyora Binder, Punishment Theory: Moral or Political?, 5 Buff. CRIM. L. REv. 321, 333 (2002) (arguing that "both utilitarianism and retributivism were originally political theories concerned with the legitimacy of punishment as an institution"). Contemporary British writers on the criminal law have tended to be more interested in questions of political theory. See, egg., Nicola lacey, State Punishment: Political Principles and Community VALUES (1994) (focusing on the punishment theory in the context of questions such as political obligation and the reinforcement of community values).

${ }^{90}$ Lest we think our government has been above the use of criminal law for blatantly "political" ends, it is always wise to remember the passage of the Alien and Sedition Acts, Act of July 14, 1798, ch. 74, 1 Stat. 596 (expired 1801); Act of July 6, 1798, ch. 66, I Stat. 577 (expired 1801); Act of June 25, 1798, ch. 58, I Stat. 570 (expired 1800); Act of June 18, 1798, ch. 54, 1 Stat. 566 (repealed 1802), - an attempt by some of the "founders" to use the criminal law to punish the members of a dissenting party. See Michial kent Curtis, Free Speech, "The People's Darling Privilege" 52-79 (2000) (discussing the history of the Sedition Act controversy); id. at 102 (quoting St. George Tucker as urging that these laws would mean that an administration might "'consider[ ] every thing as a crime against the government, which might operate to their own personal advantage"'). 
have read, in our history books, of Stalin's jailing of his enemies, of Hitler's vision of treason, and even of the grave American misuse of the criminal law to disenfranchise and enslave African Americans in the post-Civil War era. ${ }^{33}$ Indeed, if we pause for a moment, we may realize that no democratic system may sustain itself if its people fear corruption or violence (as recent experience in the new easternEuropean democracies quite clearly demonstrates). ${ }^{34}$ Finally, we may remember that no government that uses the criminal law to oppress its citizens may claim the title of a republic. As Elizabeth Anscombe

31 See PETER H. Solomon, JR., SOVIEl Criminal Justice Under Stalin 232-44 (1996) (discussing Stalin's use of the justice system for his own political ends). As Solomon insists, Stalin used the criminal law not just for terror alone, but also as "an instrument of rule." Id. at 1 . In fact, Solomon stated:

From the early 1930s Stalin made Soviet criminal law his own. Virtually every change bore the mark of his hand, and he used the criminal law for many purposes-to squeeze grain out of hungry peasants, to pressure and scapegoat his officials, to reverse the decline in the birth rate, to inculcate labor discipline in the workforce-as well as to deter juvenile delinquency, hooliganism, and theft. In the process, Stalin extended the scope of the criminal law beyond its usual functions and made punishments unusually severe. Id. at 4 .

${ }^{32}$ On Adolf Hitler's use of the criminal justice system to help him achieve his political agenda, see H.W. KOCH, IN THE NAME OF THE VOLK 38-51 (1989). For a contemporary account that emphasizes the relation between political theory and the criminal law in Germany, see E.A.M. Wedderburn, Criminal Law in the Third Reich, 48 JURID. REV. 373 (1936). See also Obituary, Franz Guentner, German Minister, N.Y. TIMES, Jan. 30, 1941, at 21 (discussing changes in the Nazi criminal law system).

33 Our nineteenth-century version of apartheid, for example, was not only an insult to individuals but also a system of white aristocracy that was perpetuated, in part, through the use of the criminal law. See ErIC Foner, ThE STORY OF AmErican FREEDOM 104 (1998) (describing how the "Black Codes ... denied blacks equality before the law ... and imposed on them mandatory year-long labor contracts ... and criminal penalties for breach of contract"). On the use of crime as inherently attached to race and thus used as a means to disenfranchise and keep African Americans off juries, see, for example, Nomis $v$. Alabama, which reported the testimony of a jury commissioner in 1935 that he did " not know of any negro in Morgan County ... who is generally reputed to be honest and intelligent and ... who is not an habitual drunkard, who isn't afflicted with a permanent disease or physical weakness ... and who has never been convicted of a crime involving moral turpitude." 294 U.S. 587, 598-99 (1935) (emphasis added); see also Hunter v. Underwood, 471 U.S. 222, 233 (1985) (striking down an Alabama constitutional provision which disenfranchised blacks on the basis of "crimes of moral turpitude" on the grounds that this was a pretext for intentional racial discrimination).

34 See SUSAN ROSE-ACKERMan, Corruption ANd Governiment: Causes, CONSEQUENCES \& REFORM 26 (1999) (stating that "pervasive corruption undermines the legitimacy of government"); Amy L. Chua, Markets, Democracy, and Ethnicity: Totvard a New Paradigm for Law and Development, 108 YALE L.J. 1, 56 (1998) (noting, in the context of developing democracies, how "too much corruption effectively can subvert the political process, replacing democracy with kleptocracy"). 
once put it, violence may present the "fundamental question of political theory."

To see how this is reflected in the criminal law, however, one must put to the side some conventional ideas. Standard criminal law scholarship has been largely allergic to political theory. Indeed, by the 1970 s and 1980s, there was a consensus within the academy that all of the most important theoretical questions in the criminal law were about individuals: individual "self-control," individual dangerousness, and individual culpability." From this crude consensus on individualization appeared an odd and unexamined corollary: that the defendant and the victim exist in some kind of "separate sphere" from the state and society and that it is the project of a progressive criminal law to protect defendants by maintaining this separation; to make their plight more and more individualized, more and more the product of a strange psychology, a rotten family background, or the effects of a peculiar syndrome. ${ }^{37}$

\footnotetext{
45 Anscombe stated:
}

The parent may in effect say "Don't hit your little brother, or I will hit you." What is the difference-is there a difference-between his threat and the threat of the child he so threatens? After all, the little brother may have been doing something quite unfair. The same question arises about the violence of the state. I judge that this is the fundamental question of political theory.

Elizabeth Anscombe, On the Source of the Authority of the State, in 20 RATIO 1, 8 (Stephan Köner ed., 1978). For an extraordinarily clear introduction to the topic, see JEAN Hamp'Ton, Pollt'ical. Philosopliy 3-38 (1997). See also Murphy \& Col.eman, supra note 27, at 114-17 (addressing the role of the state in executing the criminal law).

It6 1 refer here to the principal "theories" of culpability typically debated in the criminal law academy. On choice and self-control, see HART, supra note 4, at 227-30; on choice versus character, see R.A. Duff, Choice, Character, and Criminal Liability, 12 LAW \& PHII.. 345, $361-70$ (1993); Michael S. Moore, Choice, Character, and Excuse, 7 SOC. PHIL. \& POL'Y 29, $31-58$ (1990). On capacity for choice, see Peter Arenella, Convicting the Morally Blameless: Reassessing the Relationship Between Legal and Moral Accountability, 39 UCI.A L.. REV. 1511, 1516 (1992). Newer theories have suggested a move away from choice toward a focus on character and virtue, see Dan M. Kahan \& Martha C. Nussbaum, Truo Conceptions of Emotion in Criminal Latw, 96 CoLUM. L. REv. 269, 299 (1996) (explaining that the evaluative conception of liability favors holding individuals responsible for their character and emotions), and on virtue and culpability, see Kyron Huigens, Virtue and Criminal Negligence, 1 BUFF. CRIM. L. REV. 431, 447-58 (1998) (favoring a virtue-ethics theory of criminal law that rejects the Model Penal Code's emphasis on consciousness of harm).

${ }^{37}$ Indeed, if there were a single principle that could be identified as unassailable within the criminal law scholarship of the latter half of the twentieth century, it would be the virtue of individualization (the idea that we can save defendants from the wrath of the state by ever more particularly describing their character, characteristics, background, or virtue). See infira notes 141-48 and accompanying text (discussing individualization). 
This view, however inarticulate, cannot be a complete explanation of the criminal law. As many have recently shown, there is a wealth of argument and data suggesting that social norms, status relations, and culture more generally help to "construct" the law's very attention to what is individual." ${ }^{38}$ Moreover, there is reason to believe that just as social norms are upwardly mobile, so too are commonly held political norms. To believe, for example, that the most important task of the criminal law is to create a barrier between state and individual is to adopt, implicitly at least, an operative political theory, one informed by libertarian norms. Depending upon whose liberty "counts"-defendant or victim-such a theory either exults in punishment (protecting the liberty of the victim) or denies its possibility (protecting the liberty of the defendant). Not surprisingly, to the extent these political views find themselves reflected in the arguments of courts, commentators, and the public, they result in claims that lurch wildly from one side of the libertarian equation to the other, from defendants' rights to victims' rights and back again.

All of this has led to a criminal law scholarship that has failed to give much credence to the influence of political norms or political theory, whether those norms emanate from history, contemporary political discourse, or doctrine itself. ${ }^{3 !}$ This intellectual inattention should seem odder for two important reasons: First, it should seem odder if we are willing to grant the thesis that norms of all kinds have an influence on the criminal law. Second, it should seem odder given the general unwillingness, elsewhere in the law, to rigidly separate the public from the private. Once upon a time, we thought that the market was the repository of an assumed separate sphere, a place where, without question, individuals existed apart from the state." The New Deal changed that, at least in part, by reimagining "liberty" not as a quality of a privileged few but as a lived, and potentially exploitative,

38 My own view is that the very concept of individualization is historically contingent. At the beginning of the twentieth century through the $1930 \mathrm{~s}$, individualization was associated with burgeoning social sciences and psychologies of classification; today, however, it reflects a more modern inquiry into internal subjectivities. See DAvid GARLAND, PUNishmeNT AND WElfare: A History of PENAL STRATEgies 28, 83-84, 89-90 (1985) (discussing individualization as it developed in contrast to the classical school); $c f$. George P. Fletcher, The Individualization of Excusing Conditions, 47 S. CAL. L. REV. 1269, 1299-1309 (1974) (outlining the modern view of individualization).

${ }^{39}$ Fletcher, supra note 28 , at 287.

4) See, e.g., Lochner v. New York, 198 U.S. 45 (1905) (upholding the general right to make a contract as part of Fourteenth Amendment liberty). 
relation between employer and employee." Once upon a time, we thought that the family was a place of privacy, a place where, without question, individuals existed apart from the state. Feminism changed that, at least in part, by reimagining the family as a set of gendered, and therefore potentially subordinating, relations. In what follows, I urge that the criminal law be subjected to a similar intellectual transformation, to an imagined economy of relations between citizens and their state.

Do not misunderstand: my argument is not that we jettison concern for the individual; indeed, it is precisely the opposite. Just as in constitutional law, structure and relation ${ }^{42}$ may work together to protect individuals, so too they may in the criminal law. ${ }^{13}$ Perhaps more importantly, as the reader will see later, ${ }^{41}$ the traditional view that defenses are only meant to protect individuals-as-individuals is not normatively benign; this view can backfire by implanting state misconduct

$"$ E.g. W. Coast Hotel Co. v. Parrish, 300 U.S. 379 (1937) (rejecting a constitutional right to contract and including government regulation in Fourteenth Amendment liberty).

"2" There is another potential confusion that deserves explanation: the use of the term "relational" may conjure images of a debate between feminists and others about the nature of rights. I confess that the theory presented here will not be seen as "feminist" by many who may mistake its reliance on liberal political theory for advocacy rather than defense. For those disappointed, I note here that this does not mean that the theory will not help women (in fact, I think it does); indeed, as I argue later, this approach helps to explain to those who have dismissed feminism why it has and should have such an influence on the criminal law. It is not a theory, however, that depends upon the description, for better or worse, of women, nor is it "woman centered," nor does it ask the "woman question," all of which strategies repeat the descriptive individualism of crude liberal thought in female guise. For my views on the relational and feminism, see my article, Law's Constitution: A Relational Critique, 17 Wis. WomeN's L.]. 23, 23-56 (2002), where I argue that relational issues are "known by, and important to, feminism," yet also "beyond feminism ... [and] important to our ideas of constitution and law itself." For arguments that classical liberalism does not depend upon atomistic individualism to the exclusion of claims of equality, see HOLMES, supra note 25, at 19097. See also MONTESQuiEu, supra note 27, bk. V, ch. 3 ("A love of the republic in a democracy is a love of the democracy; as the latter is that of equality.").

43. It is not a particularly controversial position within the conventional theory of public law that structural and individual arguments may happily coexist and reinforce each other. Indeed, almost no one in constitutional law doubts that constitutional structure may protect individuals: some argue that this is the very reason for our constitutional structure. Seg CHARLES L. BLACK, JR., STRUCTURE ANd RELATIONSHIP IN CONSTITUTIONAL LAW 33-37 (1969) (setting forth structural arguments that protect individual rights, such as the freedom of speech); Akhil Reed Amar, The Bill of Rights as a Constitulion, 100 YALE L.J. $1131,1132-33$ (1991) (arguing that the Bill of Rights serves structural purposes).

Infra Part IV. 
or inequalities within the very minds of those its adherents aim to protect.

\section{RECONCEPTUALIZING CRIMINAL LAW DEFENSES}

Recently, Professors Schulhofer and Fletcher have politely disagreed on a question of criminal law theory. Professor Fletcher has renewed his call, issued long ago, for close study of political theory and the criminal law. ${ }^{4:}$ Professor Schulhofer has wondered whether such a view can give us any understanding of the real-life problems raised by the criminal law. ${ }^{4 ;}$ Both scholars seem to me to be right. Professor Fletcher is right that violence poses a fundamental question for the organization of the state. Professor Schulhofer is right that we have yet to see scholarship in the criminal law that sustains this idea in anything but the most abstract of terms. In what follows, I attempt to cash out the claim for political theory in terms of collateral and institutional effects, ${ }^{.7}$ and I aim to do it in the most difficult cases, the ones where we seem to have the most individualized rules-criminal law defenses.

\section{A. Self-Defense}

Let us begin with a well-known and controversial self-defense case, People v. Goetz. ${ }^{48}$ Theorists love Goetz because it appears to pit two individualized versions of self-defense against each other. Traditionally, self-defense is considered a justification: the defendant is seen as meriting a defense because he had to make a "choice of evils." Some

45. See, e.g., George P. Fletcher, The Nature and Funclion of Griminal Theory, 88 CAL. L. REV 687,698 (2000) (insisting that " $[\mathrm{g}]$ iven the centrality of political legitimacy in the criminal law, one can only be amazed at the extent to which the question is ignored").

"Se Stephen J. Schulhofer, The Mathematician, the Monk, and the Vilitant: Reflections on the Role of Criminal Law Theory, 88 CAL. L. REv. 705, 707 (2000) (arguing that "[c]ompeting theories of the state rarely yield discrete, incompatible prescriptions for concrete cases").

${ }^{47}$ Special thanks go to Professor Schulhofer for politely emphasizing this as a way to grab hold of this approach.

${ }^{18} 497$ N.E.2d 41 (N.Y. 1986). On the history and meaning of Goetz, see George Fletcher's review of the case, George P. FlETCHER, A Crime of SElf-Defense: BERNHARD GOETZ AND THE LAW ON TRIAL (1988). Croetz shot at four black youths on a subway and was ultimately acquitted. Jay Maeder, The Subway Vigilante, N.Y. DAILY News, Nov. 8, 2001 , at 79.

"1" "One who is not the aggressor in an encounter is justified in using a reasonable amount of force against his adversary when he reasonably believes . . he is in immedi- 
modern scholars have disagreed with this assessment, recharacterizing the defense as a reflection of the subjective and psychological pressures of the "uplifted knife," and have sought, as a result, to put the defense in the more individualized "excuse" camp. ${ }^{50}$ Neither categorization has convinced everyone and neither explains current doctrine. If the excuse variation were true, for example, then we would have to seriously expand the law of self-defense; if the justification variation were true, it might require us to narrow the defense quite substantially.

If the doctrine and theory disappoint, our intuitions tell a more robust, but inarticulate, story. People feel very strongly about the Goetz case. And yet they describe their emotions in ways that sound positively governmental. They tell us that Goetz "took the law into his own hands," that he was a "vigilante" or a revolutionary." The fear that appears to be expressed is that, if the law grants Goetz's defense, he will be permitted, in effect, to "legislate" for the rest of us." Put in other terms, the risk we emote in our criticisms of Goetz is a fear that a

ate danger of unlawful bodily harm from his adversary and . . the use of such force is necessary to avoid this danger." WAYNE R. LAFAVE, CRIMINAL LAW \$5.7 (3d ed. 2000).

5ee, e.g., Cathryn Jo Rosen, The Excuse of Self-Defense: Correcting a Historical Accident on Behalf of Battered Women. Who Kill, 36 AM. U. L. REV. 1 1, 17 (1986) (supporting the classification of self-defense as an excuse rather than a justification).

${ }^{51}$ An excuse variation that is subjectivist in origin would tend to expand the reach of self-defense beyond the "reasonable" perceptions that typically limit it. On the other hand, a justification version might require a strong view of necessity and thus a strong objective showing that the defendant had no other alternatives; that would seem to require a retreat rule in every jurisdiction (even though we know that a majority of jurisdictions does not have such a rule). See V.F. Nourse, Self-Defense and Subjectivity, $68 \mathrm{U}$. CHI. I. REv. 1235, 1246-94 (2001) (discussing the meaning of "imminence" in self-defense doctrine).

"5e Maeder, supra note 48 (" "That man took the law into his own hands,' indignantly fumed another of the four [victims], 19-year-old career thief Barry Allen."); see also A Goelz Trial Again, WASH. Times, Apr. 10, 1996, at A16 ("When Bernie Coet\%... took the law into his hands on Dec. 22, 1984, a lot of law-abiding citizens . . were absolutely prepared to believe he'd acted in self-defense when he shot them. And a jury agreed. Mr. Goetz was acquitted of assault and attempted murder in 1987.").

"5e Cal and Mouse: The Subway Gumman on Trial, TrME, May 1 1, 1987, at 26, 26 (asking whether "the subway vigilante" was "justified in defending himself against what he saw as an imminent attack, or was he a trigger-happy racist poised to strike at the slightest provocation"); Maeder, supra note 48 ("The public support for Goetz shows that ... New Yorkers indeed have grown weary of the existing government. .. What remained to them was an act of revolution. This is what Goetz committed-and a plurality supports him.").

"See Otto Friedrich, "Not Guilty": A fury Acquits the Subtoaly Gunman, but the Argument Goes On, TIME, June 29, 1987, at 10, 11 (quoting black Police Commissioner Benjamin Ward's response to Croct\%'s acquittal as a grim " [n]o one has a license to go out and hunt anyone-black, green, yellow or whatever"'). 
constitutionalist might call "countermajoritarian," a risk that the prejudices of the few will end up governing the many. Notice that this risk and public rhetoric are not unique to the Goetz case. Indeed, it is a claim that, in theory, might be made of any defendant claiming selfdefense, or any defense for that matter. It reflects, I believe, concerns about private punishment and its tendency to be self-exempting. If we allow any defendant to exempt himself from the rules and challenge the state's monopoly on violence, we fear that he will enforce the law in ways that are excessive or partial. If, as Locke believed, men are left to privately punish, they will exempt themselves, indulge favorites, and punish too severely; "for men to be judges in their own cases, . . . selflove will make men partial to themselves and their friends."

At this point, it is important to see that the notion that Goetz may have "acted above the law" is not simply a trope, but a question of his relationship to the state. When critics say that Goetz was a vigilante, they are making a claim not only with respect to his view of the victims (that he viewed them with contempt) but also with respect to those who govern. The critics are raising the structural question of whether Goetz acted "above" the majority, enforcing a minority view by private punishment. ${ }^{57}$ Importantly, Goetz's supporters make precisely the opposite claim-that Goetz was enforcing what the "majority" really wanted, that he was a "hero" and a "patriot" for taking a violent stand

55 See Jane Maslow Cohen, Regimes of Privale Tyranny: What Do They Mean to Morality and for the Criminal Law?, 57 U. PITT. L. REv. 757, 805 (1996) ("There is no doubt we would prefer to have someone in the intolerable status of a Judy Norman invite the state's response without, in the customary phrase, taking the law into her own hands."); Disabled Woman Jailed for Killing Husband, THE HERALD (Glasgow), Sept. 29, 2001 , at 10 (reporting that a Scottish judge told a woman who killed her abusive husband "that she should not have taken the law into her own hands and that imprisonment would deter others from doing so"); Greg Hardesty, Woman Gels Six Years for Running over Husband, Courts Leslie Van Houten Acted oul of Fear in the Killing, Her Lawyer Says, ORANGe County REg. (Santa Ana, Cat.), Aug. 31, 2001, at 4 (reporting that a judge told an abused woman that "her husband's conduct was 'horrific,' but that she had no right to take the law into her own hands").

JOHN Locke, The SECONd TREATISE OF Government ch. 2, para. 87 (Thomas P. Peardon ed., MacMillan Pub. Co. 1951) (1698). To be fair, Locke is apparently "responding" to an imaginary intellectual combatant when he uses these words. He adopts this view, however, only to argue that it is insufficient because it must be applied both to the individual and to the state.

${ }^{57}$ As Guyora Binder has pointed out, the very existence of the notion of vigilantism suggests that our ideas of punishment are informed by political norms. Sonetimes, after all, vigilantes may actually do the "right thing," according to prevailing moral theory; but they never do the politically appropriate thing because, by definjtion, they fail to defer to the state. See Binder, supra note 29, at 327-28 (noting that "[t]he wrong of vigilante justice is a political wrong"). 
for the frightened everyman. The crucial point is not to resolve such arguments, nor to borrow this rhetoric, but to see how they are more than arguments about Goetz as an individual-that they are arguments made in the shadow of institutional claims.

One might object here that it is cruel and pointless to treat any defendant, even a rather unattractive one, "as if" he were the state. There is no question that the vernacular expressions are crude and overdrawn. ${ }^{5.8}$ No one believes that defendants are in fact like states; the metaphor relies not on an actual similarity of power ${ }^{501}$ but, instead, on a similarity of structure and risk. It is as if the interlocutor were saying: if we take this defendant and we multiply him over and over again to make a far larger population, what kind of a government or state would we have? If we multiply Goetz a hundred-, a thousand-, or a million-fold, will we have, as many believe, a violently imposed rule of white supremacy, or will we have corrected a failure to protect the everyman? The intellectual structure of this discourse, then, is metonymic; the defendant stands in for our fears about governance.

Lest one remain in doubt about the importance of Goetz's relation to the state, one need only consider one of the key disagreements in the case. Goetz premised his claims, in part, on the theory that he had been left to suffer several muggings with no aid from the law. ${ }^{\text {(i) }}$ If he acted as an apparent aggressor in the subway, if he jumped the gun, he seemed to say, it was not his fault, it was the fault of the state that had abandoned him. Goetz's claim was that, in fact, he had not acted "above" the law at all but, instead, had properly deferred to the state-it was simply that the state had failed him." All of this helped

${ }_{5 x}$ The vernacular judgments made about defendants-that they take the law into their own hands, that they are judge, jury, and executioner-are both false and true at the same time. They are false to the extent that they appear to end the argument or are particular to any one defendant; they are true to the extent that they reveal an important constitutive link between the criminal law and political structure. Once we focus on these judgments, moreover, we can begin to question their crude application more readily. For example, it is unclear whether calling Goetz a "legislator" or a "judge" differentiates him from any other defendant and, to that extent, the argument is singularly unilluminating, partaking of the quality more of an insult than an argument.

59 On the important distinction between violence and power, see HANNAH ARENDT, ON REVOLUTION 139-216 (1965); HANNAII ARENDT, ON VIOLENCE 35-56 (1970) [hereinafter ARENDT, ON VIOLENCE].

See Fl.ETCHer, supra note 48, at 14 (discussing Goetz's fears stemming from a prior mugging and an attempted mugging, and his frustration with the legal system's response to his victimization).

(i) $I d$ 
to support his adherents' claims that "Goetz" was a law-abiding citizen, serving the interests of "everyman."

One need not resolve such a question to see that it is not easily cabined within the minds of individuals. The standard doctrinal treatment of Goetz's claim, however, invites us to do just that. Under the standard treatment, we are forced to ask whether the "reasonable person" standard should be "subjectivized" to incorporate the particular defendant's experience of prior victimization. ${ }^{62}$ This way of phrasing the question quite obviously changes the argument from one about the proper relation of the state to the defendant to one about the qualities and characters of defendants, reasonable persons, or subjectively reasonable persons.

All of this goes some way toward explaining, in a different key, the difficulties of some of the most controversial self-defense cases of today. The case of Judy Norman is a useful example..$^{63}$ Judy Norman lived a life of terror and enslavement. She was made by her husband to prostitute herself, to sleep on the floor, and, on occasion, to eat dog food. ${ }^{64}$ After an escalating series of events, in which police were called but did not arrest her husband, Judy Norman tried to kill herself. When emergency personnel were called, her husband told them

6i2 See ill. at 41-47 (comparing subjective and objective standards for self-defense); JOHN KAPLAN ET AL., GRIMINAL LAW 620-38 (3d ed. 1996) (reviewing the degree to which the reasonable person standard should be subjectivized in cases like Goetz's and Norman's).

State v. Norman, 378 S.E.2d 8 (N.C. 1989).

i4 The court wrote:

The defendant testified that ... . [h] is physical abuse of her consisted of frequent assaults that included slapping, punching and kicking her, striking her with various objects, and throwing glasses, beer bottles and other objects at her... . [O] ther specific incidents of abuse [included] her husband putting her cigarettes out on her, throwing hot coffee on her, breaking glass against her face and crushing food on her face ....

The defendant's evidence also tended to show ... that her husband did not work and forced her to make money by prostitution, and that he made humor of that fact to family and friends. He would beat her if she resisted going out to prostitute herself or if he was unsatisfied with the amounts of money she made. He routinely called the defendant "dog," "bitch" and "whore," and on a few occasions made her eat pet food out of the pets' bowls and bark like a dog. He often made her sleep on the floor. At times, he deprived her of food and refused to let her get food for the family. During those years of abuse, the defendant's husband threatened numerous times to kill her and to maim her in various ways.

Id. at 10 . 
to let her die. ${ }^{65}$ The next day, after unsuccessfully seeking help from mental health officials and social service employees, ${ }^{\text {liti }}$ Norman killed her husband while he was asleep.

Conventional approaches toward Norman's case treat it as an obvious failure to meet the "objective" standards of self-defense law: she killed when there was no imminent threat-there was no knife above her head or fist in her face. ${ }^{67}$ And, indeed, this is precisely what the court emphasized in concluding that she was entitled to no jury instruction on perfect or imperfect self-defense. ${ }^{\text {is }}$ Scholars criticized this approach, however, and have tried to explain that Norman really had no alternative-the threat was always imminent. ${ }^{\text {i:l }}$ They have likened her to a kidnap victim who waits to kill until the most opportune moment.

1:5 On the day before the killing:

[S] heriff's deputies were called to the Norman residence, and the defendant complained that her husband had been beating her all day and she could not take it anymore. The defendant was advised to file a complaint, but she said she was afraid her husband would kill her if she had him arrested. The deputies told her they needed a warrant before they could arrest her husband, and they left the scene.

The deputies were called back less than an hour later after the defendant had taken a bottle of pills. The defendant's husband cursed her and called her names as she was attended by paramedics, and he told them to let her die. [Then the officers] chased him back into his house ... .

Ill.

${ }^{6 i 6}$ After visiting mental health personnel, Norman returned and told her husband that she was going to have him committed because of his alcoholism; he replied that he would "see them coming" and "cut her throat." Id. at 11. She also went to social services to apply for welfare; her husband followed her there, "interrupted her interview and made her go home with him." Id.

"See George P. Fletcher, Domination in the Theory of Justification and Excuse, $57 \mathrm{U}$. PITT. L. REV. 553, 567-68 (1996) (using Norman as the paradigmatic case of "doubtful imminence").

See Norman, 378 S.E.2d at 12 (holding that a jury instruction was not required for "either form of self-defense unless evidence was introduced tending to show that at the time of the killing the defendant reasonably believed herself to be confronted by circumstances which necessitated her killing her husband to save herself from imminent death or great bodily harm").

${ }^{69}$ See, e.g., Richard A. Rosen, On Self-Defense, Imminence, and Women Who Kill Their Batlerers, 71 N.C. L. REv. 371, 372-78 (1993) (examining the replacement of the imminence requirement with a broader necessity standard for self-defense, with reference to the Norman case).

${ }^{70}$ See Martha R. Mahoney, Legal Images of Battered Women: Redefining the Issue of Separation, 90 MICH. L. Rkv. 1, 92 (1991) (suggesting that "[c]ourts might see Judy Norman very differently" if they saw her case as within "the paradigm of hostages resisting their captors"). On the kidnapping argument more generally, see 2 PAUL H. 
The discourse about Norman, like that about Goetz, is one that openly embraces institutional metaphor. Critics of Norman punctuate their arguments by claiming that, in killing her husband, she acted as judge, jury, and executioner. ${ }^{71}$ Those more sympathetic to Norman invoke a different relation and set of institutional tropes; like Goetz, they claim that Norman's problem was that the law had "abandoned" her to a state of nature. ${ }^{72}$ Just as in the case of the kidnap victim, the state could not (or would not) come to Norman's rescue. And any state that leaves its citizens to the mercy of the strong is a state that has abandoned its fundamental commitment to "equal" protection of the laws. ${ }^{73}$

For our purposes, the important thing to see is not how to solve these cases but what kind of discourse they evoke. Like other selfdefense cases, the Goetz and Norman cases raise important questions about the relation of the defendant to the state. The conventional narrative imagines that the only issue in these cases is whether we base questions of liability on mind or choice, character or virtue. Indeed, Goetz and Norman are often paired in casebooks as means to debate the question about how subjectively or particularly we should "describe" the individual. ${ }^{74}$ "How should we define the reasonable person?" we are asked over and over again. ${ }^{75}$ But, if I am right, this focus

ROBINSON, CRIMINAL LAW DEFENSES $\$ 131$ (c) (1) (1984), which uses the kidnapping example to explore the imminence requirement for self-defense.

$"$ See Fletcher, supra note 67 , at 556 (" $[\mathrm{H}]$ owever tragically Judy Norman's appeals to the authorities went unheeded, she cannot put herself in the position of judge and executioner."). It should be noted that far from criticizing Norman, Fletcher is sympathetic to her and ultimately argues for making "greater use of excusing conditions." Id. at 576 .

${ }^{72} \mathrm{Cf}$. HOBBES, supra note 26 , at ch. XIII, para. 8 ("[D] uring the time men live without a common power ... they are in that condition which is called war."). Jane Maslow Cohen argues, in the context of those violent dominators who violate restraining orders, that

If an attempt to seek the protections of the law triggers an outbreak of war between a tyrant who has usurped the state's functions and the state itself . . the worst risks of such a conflict [do not] deserve to fall more greatly on his hapless subject than on the tyrant himself.

Cohen, supra note 55, at 807 .

${ }_{73}$ See Catharine A. Mackinnon, TOWARD A Feminist Theory of THE STate 24526 (1989) (arguing that the state's "systematic failure" to enforce laws purporting to protect women from violence deprives women of the "equal protection" of the laws).

${ }^{74}$ For an argument that the subjectivity/objectivity debate is undertheorized and obscuring, see Nourse, supra note 51 , at 1235 .

${ }^{75}$ For the traditional views on defining the reasonable person standard, see Symposium, Self-Defense and Relations of Domination: Moral and Legal Perspectives on Battered Women Who Kill, 57 U. PITr. L. REv. 461 (1996). 
misses the presence of another level of argument-the institutional level. Was the state's failure to protect only in Norman's head? Was it really her mind that was at issue? And, if the Goetz case was only about his state of mind, why did he argue that the state had abandoned him?

These questions suggest that a rule, like self-defense, that affects an individual defendant may also have collateral effects upon the lawabiding. Imagine that, tomorrow, the state eliminated all claims of self-defense. Even when the knife is literally above his head, the defendant has no defense; he must either die or, if he defends himself, go to prison for life. As we have seen above, in the discussion of Rawls's system of telishment, ${ }^{76}$ such a rule not only affects the hapless defendant who tries to defend himself but also the rest of the citizenry who look on and wonder whether "they will be next." To eliminate self-defense is to create a world in which there is fear of the violent attacker, of being assaulted and of having no recourse. But it is also a world in which citizens are likely to change their attitudes toward their government, in which the government that once was seen as protecting them has abandoned them to the violence of their fellow citizens. Perhaps then it should not be surprising that this is precisely what Norman and Goetz argued.

\section{B. Necessity}

The relation of the law-abiding to criminal law defenses is not a modern phenomenon. Indeed, one can see this connection quite clearly in one of the great old cases of the criminal law, Regina $v$. Dudley EOStephens. ${ }^{77}$ Shipwrecked and out of food and water, Dudley and Stephens cannibalized a young cabin boy, Richard Parker. One conventional way to consider Dudley $\mathcal{E}$ Stephens is to ask whether the defendants' claim lies in excuse or justification. ${ }^{78}$ If one emphasizes the defendants' lack of self-control (the natural pressures on their wills), then one takes an excuse view of the case and of a potential necessity defense-the defendants simply had no realistic psychological choice

7i) Supra text accompanying notes 8-18.

14 Q.B.D. 273 ( 1884 ).

${ }^{78}$ The standard view of necessity is that it is a justification. As one treatise puts it, "One who, under the pressure of circumstances, commits what would otherwise be a crime may be justified by 'necessity' in doing as he did and so not be guilty of the crime in question." IAFAVE, supra note 49, \$5.4(a). This view, however, is not shared by all. Professor Michael Moore, for example, takes the view that necessity may be considered an excuse. See Michael S. Moore, Causation and the Excuses, 73 CAL. L. REV. 1091, 1102-03 (1985) (discussing compulsion-based excuses). 
but to eat the young cabin boy. ${ }^{79}$ If one focuses, instead, on the substance of the defendants' choice-between one life and five-one takes a "balancing of evils" or a justification approach. ${ }^{80}$ Neither argument is conclusive, for, if extended, each seems to yield rather unpleasant conclusions familiar to moral theorists-doctors dismantling one live body to save five patients, and psychopaths claiming excuses simply because they could not control their compulsion to murder. ${ }^{81}$ And indeed, neither doctrine nor theory has embraced either alternative-excuse or justification-with complete confidence.

This standard debate occludes much about necessity claims. Such claims often fail for reasons far afield from the defendant's psychology, felt coercion, or the balancing of evils. Consider the protestors at a nuclear power plant ${ }^{82}$ or an abortion clinic $^{8: 3}$ - a common form of modern necessity case-or even the man who commits arson to save a burning town. All of these claimants might assert plausible claims in the form of excuse (I could not help myself) or justification (I did the. right thing). But they all are likely to fail in the face of two additional factors-time and alternatives. ${ }^{84}$ In the firebreak case, if there were

79) See, e.g., Moore, supra note 78, at 1102 (noting that when necessity is recognized as an excuse, it is put in terms of "irresistible force" and "overwhelming pressure" on the individual).

${ }^{80}$ For instance, LaFave wrote:

The matter is often expressed in terms of choice of evils: When the pressure of circumstances presents one with a choice of evils, the law prefers that he avoid the greater evil by bringing about the lesser evil. Thus the evil involved in violating the terms of the criminal law (taking another's property; even taking another's life) may be less than that which would result from literal com-

pliance with the law (starving to death; two lives lost).

LAFAVE, supra note $49, \$ 5.4(\mathrm{a})$. For an excellent defense of a different right-based notion of necessity, see George Fletcher, The Right and the Reasonable, 98 HARV. L. REV. 949 (1985).

${ }^{81}$ See SANFORd H. Kadish \& STEPhen J. SCHulhorer, Criminal LAW ANd ITS PROCESSES 860-80 (6th ed. 1995) (discussing the idea that a net saving of lives alone is not enough to justify the application of the lesser evil or necessity doctrines).

"Cases dealing with protestors at nuclear power plants include People v. Hubbard, 320 N.W.2d 294 (Mich. C.t. App. 1982); State v. Warshow, 410 A.2d 1000 (Vt. 1979).

8.9 Cases discussing the availability of the necessity defense for protesting outside abortion clinics include Alison v. Birmingham, 580 So. 2d 1377 (Ala. Ct. Crim. App. 1991); Cleveland v. Anchorage, 631 P.2d 1073 (Alaska 1981); People v. Garziano, 230 Cal. App. 3d 241 (Cal. Ct. App. 1991).

See generally United States v. Schoon, 971 F.2d 193, 195 (9th Cir. 1992) ("To invoke the necessity defense ... the defendants colorably must have shown that: (1) they were faced with a choice of evils ... ; (2) they acted to prevent imminent harm;... and (4) they had no legal alternatives to violating the law."). For further examination of the issue of legal alternatives, see, for example, Bird $u$. Anchorage, 787 P.2d 119 
time to call the fire department, the claim would fail under the rule that there needs to be an "imminent" threat." Similarly, the political protestors are likely to find their claims rejected because they had the time and opportunity to protest lawfully-they might have lobbied the legislature or urged political change. ${ }^{\text {ti }}$ As one commentator has put it, "if ... there is open to [the necessity claimant] a third alternative ... [other] than ... violating the law, he is not justified in violating the law."

The necessity defense demands deference to the state for reasons we have already seen under the more colloquial label of "taking the law into one's own hands." As one court has put it: "In a society based on democratic decision making, . . . a protestor cannot simply assert that her view of what is best should trump the decision of the

(Alaska Ct. App. 1990); Buckley v. City of Falls Church, 37J S.E.2d 827 (Va. 1988); State v. Hom, 377 N.W.2d 176 (Wisc. Ct. App. 1985), affd, 407 N.W.2d 854 (Wisc. 1987).

".5 Se LAFAVE, supra note 49, $\$ 5.4$ (d) ("It is sometimes said that the defense of necessity does not apply except in an emergency-when the threatened harm is immediate, the threatened disaster imminent.").

si See Schoon, 971 F.2d at 197-99 (holding that "necessity can never be proved in a case of indirect civil disobedience" because "lawful political action" serves as a "reasonable alternative"); see also LAFAVE, supra note $49, \$ 5.4$ (a) ("The defense of necessity is available only in situations wherein the legislature has not itself, in its criminal statute, made a determination of values.").

${ }^{87}$ LAFAVE, supra note $49, \$ 5.4$ (d) (5). The rule of legislative alternatives, as demonstrated in Schoon, makes clear that those who oppose abortion or nuclear power or even segregation cannot use violence to contest legislative judgments. See Schoon, 971 F.2d at 197 ("'In a society based on democratic decision making, this is how values are ranked-a protestor cannot simply assert that her view of what is best should trump the decision of the majority of elected representatives." (quoting Brent D. White, Comment, Political Protest and the Illinois Defense of Necessity, 54 U. CHI. I. REv. 1070, 1083 $(1987)))$. It is fairly easy to imagine that, without such a limit, one might end up with a set of violent mini-states, one supporting abortion rights, the other opposing Islam, the other defending trees with axes. Whether one thinks this a good or bad idea, it is the compromise that a state makes, in my view, to avoid a criminal law that embraces violent political agitation. Like Socrates and Martin Luther King, Jr., the civil disobedient must write his pleas from jail. This, by the way, is not a comment on the morality of their claims, but simply their methods in a majoritarian state.

This fear is expressed in both popular and legal accounts. See Schoon, 971 F.2d at 197 ("The law could not function were people allowed to rely on their subjective beliefs and value judgments in determining which harms justified the taking of criminal action."); see also Gwen Ifill, Clinton Signs Bill on Abortion Protest Penalties, SEATTLE POSTINTELligencer, May 27, 1994, at A3 (quoting President Clinton at the bill-signing ceremony as saying, "No person seeking medical care, no physician providing that care should have to endure harassments or threats or obstruction or intimidation or even murder from vigilantes who take the law into their own hands because they think they know what the law ought to be"). 
majority of elected representatives." ${ }^{* 4}$ The critic of necessity fears that violent opponents of the draft or abortion or nuclear power have acted "above" the state, exempting themselves from rules applicable to others. This, in turn, implicates courts' view of the proper approach toward necessity claims. As one judge opined: "In some sense, the necessity defense allows us to act as individual legislatures, amending a particular criminal provision or crafting a one-time exception to it ...."\%

If any of this is right, then we may present an alternate account of the necessity defense. We can begin to see that the doctrine of necessity does more than simply focus on individuals' minds or choices and, indeed, that it cannot be explained (in full) without a consideration of its constructive effects. To avoid the fear that defendants are permitted to "legislate," the doctrine is constructed to remit claimants to "alternative" procedures and, in political cases, to exhaust their remedies before the legislature. At the same time, the defense remains for cases where the state is unavailable. If the defendant has, in effect, done something (like creating a firebreak) that "stands in" for what the law itself would have done when the state is absent, then to punish that person is, in effect, to punish the innocent. And, as we have already seen from our consideration of the institution of "telishment," punishing the law-abiding/innocent can pose hazards not only for defendants but for the rest of the liberal polity. Thus, the defense remains available, a signal that, when there is no policeman at hand, the law-abiding will not be punished for, in effect, abiding by the spirit of the law.

This understanding of the necessity defense may help to clarify the difficulties and the compromises of our most notorious necessity case, Dudley $\mathcal{F}^{2}$ Stephens, because it highlights the importance of collateral effects not only on other citizens but also on citizens' relations to their government. Dudley $\mathcal{F}^{2}$ Stephens is a wonderful case because it is quite literally a case about governing. ${ }^{9 !}$ There is no clearer case of the absence of the state: there was no one to call and no apparent rescue in the offing. Governing in this state of nature was the issue of the day. Both the popular and the lawyerly focus, at the time, was on the "cus-

Schoon, 971 F.2d at 197.

(d) 1 at $196-97$.

${ }^{91}$ The odd truth about the case is, of course, that the defendants were precluded from asserting the necessity defense. See Robert C. Berring, Book Review, 73 CAL. L. REv. 252, 257 (1985) (indicating the trial judge's refusal to let the defense attomey argue the law of necessity). 
tom of the sea," or the practice in which stranded sailors were to "draw lots" to determine who would be eaten." The drawing of lots was, of course, a crude form of governance: $:^{! 3}$ it was a lottery aimed at preventing dying men from preferring themselves, from being "judges in their own cause." This procedure invariably failed its own aspirations; despite its ambitions to protect the least powerful, the drawing of lots was not above gerrymandering. Too often, the least powerfulthe slaves, the foreigners, and the young-were the ones whose lots came up short. ${ }^{1 / 4}$

With this perspective in mind, it is possible to understand more clearly why the English court could charge Dudley and Stephens with errors of government; put in other words, why the opinion urged that necessity was a "tyrant's plea." As in contemporary necessity cases, where countermajoritarianism is feared, so too was it in Dudley $\mathcal{E}^{2}$ Stephens. The judges warned of the dangers of a law that allowed the defendants to change the very "definition of the crime," by exempting themselves from general prohibitions. The court asked, "Who is to be the judge of this sort of necessity? By what measure is the comparative value of lives to be measured? Is it to be strength, or intellect, or what?" If the decision to live or die were left in the hands of the men

92 See A.W. Brian Simpson, Cannibalism And THE Common law: THE Story of THE Tragic LAST VOYAGE OF THE MICNONETTE AND THE STRANGE LEGal PROCEEdincs TO WHICH IT CAVE RISE 60-66 (1984) (examining testimony and accounts to determine whether Dudley and Stephens discussed drawing lots); see also KAPLAN ET AL., supra note 62, at 669 n.17 ("Indeed, Professor Simpson reports an oral tradition that Dudley $\xi^{2}$ Stephens were prosecuted solely because they did not draw lots."). One scholar observed:

So long and entrenched was the tradition of cannibalism on the seas that public sympathy in the sailing ports was unquestionably behind Dudley and Stephens. Even the consumed Mr. Parker's older brother sought out the defendants in jail to shake their hands in a symbolic gesture of understanding. The only point that troubled the public mind was the failure to cast lots to determine the victim.

Berring, supra note 91, at 255 (citation omitted).

:3ee, e.g., MONTlsquieu, supra note 27, at bk. II, ch. 2 ("The suffrage by lot is natural to democracy; as that by choice is to aristocracy. The suffrage by lot is a method of electing that offends no one ..." (citation omitted)).

${ }^{94}$ See, e.g., SIMPSON, supra note 92, at 60-66, 123-24 (recounting instances when a young boy, a foreigner, and a slave were each the first to be cannabalized on their respective ships).

95 Regina v. Dudley \& Stephens, 14 Q.B.D. 273, 288 (1884) (quoting JOHN MILTON, PARADISE LOST bk. 4, 1. 394 (Alistair Fowler ed., Longman Group Ltd. 1971) $(1667))$

96.
Id.
Id. at 287. 
on the boat, its execution would be self-interested and partial: "[T]he principle leaves to him who is to profit ... to determine the necessity which will justify him in deliberately taking another's life to save his own." Not surprisingly, Dudley and Stephens had chosen "the weakest, the youngest, the most unresisting." This was a plea of the strong against the weak, the plea of a "tyrant" who held powers of both legislation and execution in the same hands."

I believe that, in Dudley $\mathcal{E}$ Stephens, the court decided as it did less because of the defendants' evil minds or growling bellies than because the court was worried that the "custom of the sea" was a method of governance too easily subject to abuse. We know this, in part, because history tells us that the case was constructed for the precise purpose of announcing a new rule that would change the "custom of the sea."101 Ultimately, of course, to modern readers, this raises its own concerns: who, after all, was the "tyrant" when the government had constructed the case to "change" the rules in the middle of the game? Was not the court the one that was "legislating" in ways that the defendants could not have anticipated? So thought much of the public, whose only complaint was that the defendants had not abided by the existing rules, the drawing of lots. ${ }^{102}$ Indeed, this ambivalence was reflected in the ultimate judgment: a new rule was announced for future cases but not at the defendants' expense; their sentence was commuted by the Crown to six months in prison. ${ }^{113}$

98 Id.

(9). Id.

${ }^{1(k)}$ It is one of the most hallowed statements of the "separation of powers" that the joining of these powers in a single person is the height of despotism. As Montesquieu made clear, this is because of self-preference-the ruler with legislative and executive powers may create self-preferential rules that are then executed self-preferentially. See MONTESQUiEU, supra note 27, at bk. XI, ch. 6 ("When the legislative and executive powers are united in the same person, or in the same body of magistrates, there can be no liberty; because apprehensions may arise, lest the same monarch or senate should enact tyrannical laws, to execute them in a tyrannical manner.").

${ }^{101}$ It is clear the sailors knew the then-current law of the sea, SIMPSON, supra note 92, at 140, and equally clear that the court's judgment in Dudley $\mathcal{F}$ Siephens was meant to change that law, see id. at 240 ("No doubt the reason for going through with the formal death sentence was to dramatize the condemnation of the custom of the sea.").

${ }^{102}$ See Berring, supra note 91 , at 255 (noting that the public viewed the "failure to cast lots" as the only controversy).

${ }^{103}$ Brian Simpson tells us that this kind of pardon had been contemplated from the beginning. See SIMPSON, supra note 92, at 240 ("[I]t had been assumed throughout [the trial] that [Dudley and Stephens] would promptly be pardoned."). This is not simply an isolated case of "compromise" but an incidence of what Meir Dan-Cohen has called "selective transmission," the tendency of the law to modulate or obfuscate what amount to "decision rules." See Meir Dan-Cohen, Decision Rules and Conduct Rules: On 


\section{Provocation}

Since necessity and self-defense are most often considered justifications, one might question whether this kind of analysis illuminates more traditional "excuses," which tend to focus on individual personality. Here, I aim to widen the field and make the more difficult argument that even defenses that appear far more comfortable in the "excuse" or "partial excuse" camp may be understood at an institutional level. Indeed, I think that such an account explains some of the oddities of both the law of provocation and of insanity. Neither defense, it turns out, is solely about mind or passion; both are constructed in the image of their collateral effects on the law-abiding.

Even more than self-defense or necessity, ideas of provocation have vacillated greatly within criminal law theory. ${ }^{104}$ The traditional theory of provocation imagines it as a partial justification-a defendant provoked to kill by a wrong inflicted upon that defendant is partially justified in killing if a reasonable person in the situation would have been similarly provoked. ${ }^{105}$ The provoking wrongs originally condoned by the common law-among them, adultery, attack, and false arrest-have in large part receded to the demands of the reasonable man. ${ }^{106}$ Today, many jurisdictions simply require that any provocation will do as long as a reasonable person would be similarly pro-

\footnotetext{
Acoustic Separation in Criminal Laww, 97 HARv. L. Rev. 625, 635-36 (1984) (stating his hypothesis that the law engages in "selective transmission" strategies to pursue particular "decision rules"). For example, as Cohen explains, the Indian Penal Code drafted by Lord Macauley specifically denied the defense of necessity and referred the matter to the sovereign for a determination of clemency. See id. at $640 \mathrm{n} .35$ (discussing Macaulay's concern that "allowing defenses based on 'the desire of self-preservation' would be widely abused and would lead people more readily into life-threatening situations"). "Selective transmission" in this sense reflects a desire to limit "legislation" (the assertion of conduct rules) and the perils of execution (self-exemption and ex post facto determinations). $I d$.

1h4 See Glanville Williams, Provocation and the Reasonable Man, 1954 CRIM. L. REv. 740, 740-42 (raising fundamental questions about the theory of provocation); see also Victoria Nourse, Passion's Progress: Modern Law Reform and the Provocation Defense, 106 YALE L.J. 1331, 1341-42 (1997) (discussing the "disarray" of ideas of provocation).

"1t:5e Joshua Dressler, Provocation: Partial Justification or Partial Excuse?, 51 MOD. L. REv. 467, 467-72 (1988) (describing traditional and modern views of provocation); Nourse, supm note 104, at 1339 ("[T]he earlier view is roughly associated with the common law and regards provocation as partial justification.").

1): See LAFAVE, supra note $49, \$ 7.10$ (explaining that discussions of "provocatory conduct" are actually considerations of reasonableness).
} 
voked into passionate homicide. ${ }^{107}$ The quandary that arises, of course, is whether any killing is "reasonable" in this sense. ${ }^{108}$

Partially in response to these questions, the more modern theories of provocation have tended to focus on an excuse version of the defense-a version that emphasizes the individual's lack of self-control. Borrowing concepts from diminished capacity law, for example, the Model Penal Code's version of provocation seems to have almost completely jettisoned the justification theory. ${ }^{109}$ Instead, the Model Penal Code provides a partial defense in any case in which the defendant lacked self-control because of "extreme mental or emotional disturbance." 110 Provocation, in its "reform" incarnations, then, has tended to transform questions that used to be about the reasonableness of provoking conduct into questions of individual psychology and reasonable minds."

That provocation falls in the excuse or partial-excuse camp, however, does not eliminate the possibility of collateral effects. It is not only the defendant with a weak self-defense claim but also the one with a weak provocation claim whom critics charge with taking the law into his own hands. Imagine a defendant who argues that he was prompted to violence by a passionate response to the unreasonable

167

See, e.g., Howell v. State, 917 P.2d 1202, 1209 (Alaska Ct. App. 1996) (explaining that Alaska's legislature has codified the "traditional" doctrine of provocation, so that if a "reasonable person" would have believed the victim had engaged in a serious provocation, the defendant may be partially justified for his actions); People v. Steele, 47 P.3d 225, 240 (Cal. 2002) (indicating that California's "reasonable person" requirement demands that for the provocation defense to be successfully invoked, the objective, reasonable person would have to have been provoked while in the defendant's predicament); Savage v. State, 558 S.E.2d 701, 703 (Ga. 2002) (deciding that a defendant may only receive a voluntary manslaughter charge when he has demonstrated that he acted out of passion in response to a provocation that would have caused a reasonable person to act similarly).

${ }^{108}$ See Williams, supra note 104, at 742 (questioning whether any provoked killing can be held reasonable because reasonable people do not kill).

MODEL PENAL CODE $\$ 210.3(1980)$.

iil Id.

II See id. $\$ 210.3 \mathrm{cmt} .5$ at 55 (emphasizing the subjectivity of the inquiry under section 210.3); id. at 57 (questioning the common law's "confining" doctrine in categories of provocative conduct); $i d$. at 60-61 (emphasizing that section 210.3 "substantially enlarge [s]" the scope of common law provocation, in part by eliminating categories and relying on the actor's belief); id at 61-62 ("Most importantly, the Model Code qualifies the rigorous objectivity with which the common law determined adequacy of provocation."); id. at 62-63 (emphasizing the relative subjectivity and flexibility of the Model Penal Code's reference to the actor's "situation"); id. at 63 ("In the end, the question is whether the actor's loss of self-control can be understood in terms that arouse sympathy in the ordinary citizen."). 
"nagging" of his wife ${ }^{112}$ or one who claims to have been inspired to kill by an overwhelming fear of African Americans based on "reasonable racism." ${ }^{\prime \prime 3}$ As in Goetz or Norman or Dudley $\mathcal{E}^{2}$ Stephens, the critics' claims express a fear that the law will embrace the defendants' own partiality in the guise of a "reasonably" provoking emotion. Put less colloquially, the fear is that, by permitting such a defense based on "wifely" nagging or the "natural" aggression of blacks, the law will be perceived, not simply by defendants, but by the law-abiding, as endorsing claims of violence based on "reasonable" emotions that amount to what the law, in other places, would declare to be sexist or racist. In a world in which the law embraces these emotions as reasonable, critics have a right to fear that the law has upended itself and, in effect, changed the relation between citizens and their government.

If this is right, then it is not enough to view the provocation defense as a reflection of the defendant's individual psychology. The provocation defense does not rely just upon emotion but upon emotion linked to claims of "reasonableness." Those claims are, in turn, often borrowed from the normative relations of the parties.

The provocation defense, like self-defense, takes "two"-it takes a defendant's responding to another person and, in turn, requires, for its success, that the defendant's claim be embraced by the state. Just change the relational contexts of the cases and this becomes clearer. One co-felon nags another about bringing the wrong gun; can the cofelon claim provocation? We may hope to measure this defendant's anxious pulses and neural activity but we know that there is no technology, no internal diagnostic machine, to effect such a result. And in the absence of such an investigation, we are left to our social resources, relying on our judgments of the facts of "human nature." We judge our squabbling co-felons by norms about their behavior and their relationships to each other and to the state.

If provocation may elicit fear that the law will embrace relational norms that elsewhere would clearly be seen as "legislating," it also

112 E.g., People v. Roche, 772 N.E.2d 1133 (N.Y. 2002).

113 See Jody D. Armour, Race Ipsa Loquitur: Of Reasonable Racists, Intelligent Bayesians, and Involuntary Negrophobes, 46 STAN. L. REV. 781, 782-83 (1994) (discussing a claim of self-defense based on a claimed reasonable consideration of race).

${ }^{114}$ See HART, supra note 4 , at 33 (referring to "inferences from 'common-sense' generalizations about human nature" in proof of provocation). The reference to human nature is certainly not Hart's alone. This is a rather ancient idea. See HoBBES, supra note 26, at ch. XXVII, paras. 21-26 (discussing crimes, excuses, and extenuating circumstances and stating that "Nature ... compels" a person to break a law in some situations). 
raises precisely the opposite fear-that the state will deny the defense in an appropriate case. As we have seen above in cases of self-defense and necessity, there is more than the risk that the defendant will ask us to embrace a norm-like reasonable racism-that legislates against the grain. There is, as well, precisely the opposite risk-that the state will favor the prejudices of the many at the expense of the few. This does much to explain the oddities of the Model Penal Code's approach toward provocation. For it is this risk-the risk of majorities being partial to themselves-that appears to have propelled the drafters toward a focus on individual minds and emotional distress. The drafters' particular concern was a case involving male sodomy; they assumed that this would be the kind of claim that a majority might cieny because of homophobia (whether or not the sex was consensual). ${ }^{1.5}$ The drafters envisaged the lonely and oppressed defendant whose claim is rejected by the jury because the defendant or the conduct is morally or socially suspect.

There is no question that both of these risks are possible-the risk of a sympathetic defendant denied a defense or an unsympathetic defendant accorded one. But, in either case, and most importantly for our purposes, these risks are not based on the defendant's individuality alone. We view these risks in light of the relations apparent in the case; we view the young boy sodomized by a sadistic older man in a far different position than the co-felon nagging his co-felon. The drafters of the Model Penal Code, however, focused on one particular type of risk (majoritarian bias against minorities) and, on the basis of that risk, shifted the inquiry toward one of mind and mental disturbance. In that shift, they created the possibility that the law would, via the mind, embrace the good with the bad, the man who killed his wife for nagging and the boy tortured by an older man. For once one refuses to consider the normative relation of the defendant to the victim or the state, and is left only with a descriptive account of the defendant's mind, then almost any defendant's claim of provocation may appear plausibly "emotional." It is not only Gounagias, but also the man who

11: MODEL. PENal. CODE $\$ 210.3$ cmt. 5 at 59-60 (discussing State v. Gounagias, 153 P. 9 (Wash. 1915)); se. also Bedder v. Dir. of Pub. Prosecutions, I W.L.R. 1119, 1122-23 (Eng. H.L. 1954) (applying the test for provocation as to that of the "mind of a reasonable man" without consideration of the individual's particular condition or sensitivity). 
kills someone who parked in his parking space, ${ }^{116}$ who may appear emotionally disturbed.

All of this is made more complicated by the fact that, in provocation, one is not exonerating the defendant but simply mitigating the charge, which adds another level of analysis. We can see this most clearly if we consider one of the most sympathetic of provocation claims-that of the parent who kills the abuser of her child at the moment she learns of the abuse. We do not worry, in such a case, that the defendant has sought to impose partial, personal, or prejudiced norms about the provoking act. Unlike the defendant who kills a nagging wife or a parking trespasser, the defendant who kills the child abuser has not flouted majoritarian norms about the provoking act: The child rape is clearly and gravely wrong in a way that parking and nagging are not. In her emotion (the outraged response to the rape), the defendant looks like us. But this cannot excuse the act of killing. For, in this act, the defendant has avoided the state's monopoly on violence and dispute resolution-she may not have "legislated" improperly, but she has "executed" improperly by killing (rather than using lawful process to respond to the wrong).

Thus, in a single case, we may say both that the defendant has acted with and against the many; that she poses little risk of legislating norms contemptuous of basic social prohibitions (like the rule against rape) but that she has quite literally taken the execution of the law into her own hands. A law that failed to recognize the defendant's reasons (the rape) would seem to make the law better than its citizens (because it failed to reflect their moral norms) and a law that failed to punish (the killing) would simply repeat the same error. And so the law compromises, by reducing the verdict from murder to manslaughter, upon a showing of emotion so great as to remove the defendant from the "call of reason" and so sudden that the state could not take her place.

\section{Insanity}

I conclude this Part by considering insanity; there is no defense more clearly understood as an excuse, nor one more clearly focused

${ }^{116}$ State v. Raguseo, 622 A.2d 519, 523-25 (Conn. 1993) (describing a defendant who killed someone who parked in his parking space and then argued on appeal that the evidence established the affirmative defense of extreme emotional disturbance). 
on individual minds. ${ }^{117}$ Insanity is the "hard" case for a theory that eschews a focus on psychology and individuality and, instead, urges emphasis on the relations of defendants to victims and to the state. And yet, here too, I believe this approach has explanatory power, particularly when it comes to explaining the great, and increasing, anomalies of the insanity defense. Throughout the twentieth century, there was no more politicized, no more amorphous, claim than the insanity defense. The public has repeatedly found in the insanity defense-more than any other modern criminal law doctrine-cause for concern. ${ }^{118}$ Academics have joined in this chorus of disapproval, albeit from a different perspective, charging that the insanity defense fails to reflect a psychologically accurate vision of mind and personality. ${ }^{119}$

The most notorious of the modern insanity cases is the Hinckley case. ${ }^{120}$ John Hinckley attempted to assassinate President Reagan and claimed that he did this to continue his imagined relationship with screen star Jodie Foster. Like many cases involving the insanity defense, Hinckley's trial was one by psychiatrist; when it was over, the jury concluded that he was insane within the meaning of the law. ${ }^{191}$ The public rebelled, and Congress changed the rules, tightened the doctrine, and purported to return to the traditional meaning of the law. ${ }^{122}$ As a result of Hinckley, a number of states reformed their insanity defenses, and by 1996 a majority had returned to older formulafense).

117 See LAFAve, supra note $49, \$ 4.1$ (b) (describing the purpose of the insanity de-

II See id. \$4.l(d) (discussing the question of abolishing the insanity defense, a question typically not raised with respect to other defenses).

${ }^{119}$ See id. $\$ 4.2$ (c) (noting that the criticism of $M$ Naghten-one of the standard insanity measures, see infra note 124 (discussing the rule) -is that the test is "based on an entirely obsolete and misleading conception of the nature of insanity" (citation omitted)); see also Durham v. United States, 214 F.2d 862, 870-71 (D.C. Cir. 1954) (arguing that the $M$ 'Naghten rule reflects a view inconsistent with the "science of psychiatry").

${ }^{1006}$ United States v. Hinckley, 525 F. Supp 1342 (1981).

${ }^{121}$ See KAPLAN ET AL, supra note 62, at 745 ("There was conflicting expert testimony on each side, but Hinckley put on persuasive evidence of his psychotic obsession with Foster and was acquitted.").

${ }^{122}$ Id. ("Public opinion polls taken immediately after the Hinckley verdict was announced indicated that up to 90 percent of those surveyed favored abolishing the insanity defense... Hinckley's acquittal captured the public attention and focused lawmakers on the insanity defense to an unprecedented extent."). 
tions of the defense, ${ }^{123}$ specifically borrowing the seemingly archaic view known as the M'Naghten rule. ${ }^{12}$

The politics of the insanity defense has yielded an exceedingly wide split between the academy and doctrinal reality. By the 1960s, insanity had become the darling of criminal law scholarship. ${ }^{125}$ Judges and scholars experimented with rules that attempted to give greater psychological reality to the defense. The Durham rule, offered by Judge Bazelon, was exalted by experts for its realism; ${ }^{126}$ the Model Penal Code's proposal significantly broadened M'Naghten but continued to be criticized as unrealistic. ${ }^{127}$ Judges and scholars repeated over and over again that the traditional rule-M'Naghten-did not reflect the actual operation of mind. ${ }^{128}$ Oddly enough, even though only two jurisdictions ever adopted Durham and a minority now follow the Model Penal Code, the casebooks still teach this narrative of law-gonewrong. ${ }^{12 ! !}$

If my analysis is correct, though, we should consider that we may be asking the wrong question about the insanity defense-that our focus on individual minds has occluded a different question. What, after all, is the attraction of M'Naghten? M'Naghten demands that the de-

${ }^{12.3}$ See id. at 732 n.15 (stating that "[a]s of 1996 a majority of states were using a M'Naghtent-based test").

124 M'Naghten's Case, 8 Eng. Rep. 718, 719 (H.L. 1843), states that sanity should be presumed and insanity requires proof that the defendant did not know the nature of his act or that the act was wrong.

12: See, e.g., Caleb Foote, A Comment on Pre-Trial Commitment of Criminal Defendants, 108 U. PA. L. REv. 832, 832-46 (1960) (exploring pretrial insanity and a federal commitment statute); Richard H. Kuh, The Insanity Defense-An Effort to Combine Law and Reason, 110 U. PA. L. REV. 771, 772 (1962) (suggesting that insanity issues are improperly given to jury deliberation in light of current knowledge in psychiatry).

See LAFAVE, supra note $49, \$ 4.3($ b) ("The psychiatrists, generally, applauded the $[$ Durham $]$ decision.").

${ }_{127}$ See idl $\$ 4.3(\mathrm{e})$ (noting criticisms that the ALI test failed to "'bridge the gap that now exists between legal and psychiatric thinking" (quoting HENRY WEIHOFEN, THE

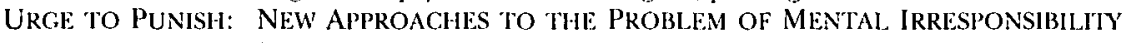
FOR CRIME $100($ (1957))).

${ }^{128}$ See, e.g., United States v. Brawner, 471 F.2d 969, 976-79 (D.C. Cir. 1972) (repeating the standard psychological criticisms of $M$ Naghten); SHELDON GL.UECK, LAW \& PSYCHIATRY: COLD WAR OR ENTANTI CORDIALI? 48 (1962) ("M Naghten proceeds upon .. . questionable assumptions of an outworn era in mental medicine . . . Not only is the famous test vague and uncertain, and not only does it embalm outworn medical notions, but. . . it is also too narrow a measure of irresponsibility."); ABRAHAM S. GOLDSTEIN, THE INSANITY DEFENSE 46-47 (1967) (explaining that, at the lime, critics of $M$ Naghten tended to "dominate the debate. The picture they present is that of a restrictive rule which reflects an outmoded faculty psychology," and "denies to the jury the "insights of modern psychology'”).

\footnotetext{
12!3 E.g., KAPLAN ET AL., supra note 62, at 734-38.
} 
fendant show either that she was completely unable to appreciate reality at the time of the crime (the venerable claim that the victim was simply a lemon) or that he could not appreciate the wrongfulness of his actions. ${ }^{130}$ Now, if one simply wanted to narrow the insanity defense to a bare minimum, to restrict its import for fear of abuse, one would simply leave the defense to the first prong-require that the defendant was incapable of appreciating reality. But that is not the doctrine; instead, M'Naghten allows the defendant to argue that he knew what he was doing-killing a person-but could not appreciate its wrongfulness. ${ }^{1.11}$

The normative quality of M'Naghten is what has disturbed mental health experts and tended to focus the critique on M'Naghten's unrealistic description of mind. But what if M'Naghten is not intended to be about mind alone? What if it is about the relation of the defendant to the law-abiding and the state? Recourse to the risks we have seen above can help to explain widespread affection for an otherwise apparently irrational doctrine. Consider the risk of legislation-the fear that insanity is some kind of unreasoning reason that, if accepted, would put the state at the mercy of those with beliefs the state denies. Put differently, the fear is that "insanity" arguments are simply manufactured excuses for bad norms (for homophobia or imagined rejection or love of violence). ${ }^{132}$ From such a perspective, the issue of control and volition (often lauded as the principal difference between modern and ancient insanity formulations), recedes before the risk of undermining majoritarian norms; since, if one is worried about countermajoritarian norms, one worries less about whether or not there is

${ }^{1300}$ Kaplan, Weisberg, and Binder explain:

The M'Naghten rule ... tells jurors simply "that every man is to be presumed to be sane, and ... that to establish a defence on the ground of insanity, it must be clearly proved that, at the time of the committing of the act, the party accused was labouring under such a defect of reason, from disease of the mind, as not to know the nature and quality of the act he was doing; or, if he did know it, that he did not know he was doing what was wrong."

Id. at 732 (quoting M'Naghten's Case, 8 Eng. Rep. at 722).

${ }^{131}$ Indeed, it is precisely this characteristic that has elicited criticism from psychiatrists. See LAFAVE, supra note $49, \$ 4.2$ (c) (3) ("A common objection among psychiatrists to the right-wrong test is that it is directed to ethical and moralistic rather than scientific concerns.").

${ }^{132}$ For an account emphasizing such fears, see the discussion of fears of homophobia and the Dan White case in GEORGE P. FIETCHER, WITH JUSTICE FOR SOME: ProteCting, Victims' RightS In CRIMINAL TRIALS 15-18 (1996). 
control than why one has lost control. ${ }^{13:}$ In a world of such fears, M'Naghten's normative and cognitive elements make a good deal of sense: the defendant who cannot appreciate social and legal norms cannot be seen as "legislating." He has no reason at all, where reason is defined as a wish to impose bad norms; the "right or wrong" test aims to ensure that he has no normative judgment at all.

Importantly, however, the normative component of M'Naghten does double duty: it not only restricts the claims of defendants but also restricts the power of the state. A defendant who cannot appreciate legal and social norms-as M'Naghten provides-not only cannot legislate, she cannot be judged according to prevailing norms. A state that would punish the insane (in the M'Naghten sense) would clearly act "above" its own citizens-it would apply a standard of judgment that the citizen could not. If punishment is legitimated at least in part based on majoritarian norms, a state that punishes someone who cannot appreciate these norms punishes for no reason. The state sacrifices the minority (the defendant) in the name of no principle; it punishes for disability alone.

The point of this discussion is not to valorize M'Naghten. Rather, it is to emphasize that there may be more at stake in the insanity defense than simply mind, mental structure, or psychology. However much we may want to remit questions of insanity to experts, a normative view of the defense has been surprisingly resilient. This resilience may reflect less about the nature of minds than it does about the collateral effects of the defense. For example, the defendant who harms others when insane differs from other defendants not only in psychology but also in the relations she creates. The defendant who kills thinking that she is squeezing a lemon expresses no contempt for her victim; she makes no claim of aristocracy-that she deserved life while the victim did not. ${ }^{19.4}$ Similarly, she makes no claim to take the law into her own hands for she does not, and cannot, understand that law. ${ }^{135}$

And yet, if we imagine a world in which the state routinely punishes the insane, we would easily complain that the state had departed

193 The issue is not, then, cognition versus control but, instead, limiting both to avoid risk of embracing countermajoritarian norms-whether one adopts a control or a cognition test.

${ }^{134}$ On the question of contempt and the notion of superiority as implicit in our blaming practices, see Jean Hampton, The Retributive Idea, in FORGIVENESS AND MERCY 111, 124-30 (Jeffrie G. Murphy \& Jean Hampton eds., 1988).

${ }^{135}$ On defiance as a component of mens rea, see Jean Hampton, Mens Rea, SoC. PHIL.. \& POL'Y, Spring 1990, at 1. 
from its commitments to protect the weak as well as the strong. For the state to punish the insane is like the state that punishes the selfdefender with no other recourse; in neither case is the state available to the defendant, in the first case because of the speed of the knife and in the second because of incapacity of mind. And, as we have learned above, where there is no alternative law-abiding mode, to punish the defendant comes very close to punishing the innocent. Whether or not M'Naghten then amounts to a realistic or even appropriate view of mind, it should stand as a floor below which a truly republican state should not go. If this is the logic of the argument, it is not, of course, its resolution. If my approach is right, then the insanity defense represents the state's commitment to a particular vision of consenting citizens and their relations to one another. M'Naghten may well be criticized for failing to provide a realistic standard for minimal participation in the community, but that is a decidedly different criticism than the one traditionally made.

Insanity bears the marks of the law-abiding in ways similar to what I have tried to show throughout this Part. My argument has been that the doctrine of defenses is constructed as much to avoid private punishment ("taking the law into one's own hands") as it is to reflect a particular view of defendants' individual character or choice or selfcontrol. This is manifested nowhere more clearly than the standard requirement of defenses that the state be unavailable-a requirement that demands deference to the state's monopoly on violence. For example, the doctrine of self-defense insists that the threat be so imminent as to prevent lawful recourse and often emphasizes this fact by requiring retreat. ${ }^{136}$ The doctrine of necessity requires that the defendant cannot take the law into her own hands-that the protester, for example, must assert her claims before the legislature. ${ }^{137}$ Similarly, duress in many formulations ${ }^{138}$ demands that, if there is an alternative, if the police may be called, that the defendant loses her claim of coercion. Provocation does not yield acquittal but only mitigates precisely because no emotion, however grave or consistent with the law, can eliminate the defendant's evasion of the state's monopoly on vio-

${ }^{136}$ See supra text accompanying notes 67-70 (discussing imminence).

137 See supra text accompanying notes 84-87 (discussing the "alternatives" requirement in necessity law).

${ }^{138}$ See State v. Crawford, 861 P.2d 791, 799 (1993) (finding evidence of compulsion insufficient to make out a claim of duress because "the required element of an imminent threat is missing, the compulsion is not continuous, and there were opportunities for escape”). 
lence. ${ }^{139}$ Finally, even insanity, that darling of excuse, depends in some of its most resilient forms upon the notion that the state is unavailable; that it provides no call to the reason of the defendant; that even if the policeman were at her elbow, the insane defendant would do the same. If this is right, then we must do better than assume that defenses are only reflections of individual defendants' characters or choices or emotional self-control. These latter concerns may be necessary but they are not sufficient to explain the criminal law of defenses that we have.

\section{The Paradox of Individualization}

At this point, it is time to reflect and respond to the inevitable objections. Some will find my approach uncomfortable and challenge it as "illiberal." They will insist that defenses are about individuals and are necessary exceptions to the general social goals of crime control. Indeed, I do differ from this view; I have offered accounts of defenses that do not rest solely upon individuality and do not claim to be "exceptions" to general ends, but instead reflect the law's collateral effects, including the demands of majorities and the state. At the same time, I believe the charge of illiberalism to be mistaken, and, in this Part, I confront that objection, arguing that defenses should be placed on stronger majoritarian ground. First, I explain that what has often appeared as the "liberal" solution to criminal justice problems may not be as "liberal" as many have hoped-that the idea that we best protect defendants by individualization may actually lead to the very oppression that we had hoped to avoid; indeed, it may implant the state within the hearts and minds of individuals. Second, I argue that, if one is looking for a liberal political theory, principles of anti-selfexemption are far more instructive, and far more grounded in traditional liberal political thought, than the hyperindividualism that has so influenced the definition of what is "liberal" in the criminal law. ${ }^{1+1}$

\section{A. Rethinking Individualization}

For some time, criminal law scholarship has been propelled by an offstage moral narrative, a story of the lonely individual pitted against

\footnotetext{
13:) See supra text accompanying note 116 (discussing provocation and the judgment about emotion versus the judgment about killing).

141 See STEPHEN HOlmes, The ANATOMY OF ANTILIberalism 237-40 (1993) (discussing the "self-exemption taboo" of liberal thought). This is also the position, I believe, of Hannah Arendt. ARENDT, ON VIOLENCE, supra note 59, at 97.
} 
a hostile community. From the middle of the 1950s through the 1980 s, this story came to yield a seeming orthodoxy that individualization was the hallmark of a just criminal law. ${ }^{141}$ As one commentator has put it, one of the "central tenets" of liberal philosophy of the 1970 s was the "idea that the defendant should get as much individualized (subjective) justice as possible."1+12 Indeed, in part because of the path-breaking work of H.L.A. Hart, ${ }^{143}$ it once seemed as if a large portion of the literature on negligence, self-defense, and provocation was devoted to the question of how "individualized" the reasonable person should be. ${ }^{144}$ This movement reached its height with proposals for defenses based on rotten social backgrounds and the transformation of general rules into more particularized syndromes. ${ }^{1.5}$

By the end of the century, however, the pendulum had swung the other way. Although individualization remained a central background norm in theoretical debates, ${ }^{146}$ there was growing concern that this

${ }^{141}$ The relevant literature ranges from the philosophical, see HART, supra note 4, at 158-85, to the philosophically minded, see Moore, supra note 78, at 1091-95, 1128-49, to the more doctrinal, see Paul H. Robinson, Rules of Conduct and Principles of Adjudication, 57 U. CHI. L. REV. 729 (1990).

${ }^{142}$ Doriane Lambelet Coleman, Individualizing/ustice Through Multiculturalism: The Liberals' Dilemma, 96 Colum. L. REV. 1093, 1095 (1996).

${ }^{143}$ For a discussion of Hart's negligence theory, see HART, supra note 4, at 136-57; on Hart's influence and the importance of individualization to the "justice" of the criminal law, see David A.J. Richards, Introduction to Symposium, Self-Defense and Relations of Domination: Moral and Legal Perspectives on Battered Women Who Kill, 57 U. PITT. L. REV. 461, 461-62 (1996).

${ }^{144}$ The questions enumerated in casebooks of the 1970s and $1980 \mathrm{~s}$ display this legacy, focusing as they so often do on how we characterize the "reasonable person," or how subjective our approach toward individual defenses should be. These issues tend to arise anywhere a "reasonable person" standard arises. In the criminal law, this covers a good deal of territory from negligence to self-defense to provocation. See, e.g., KADISH \& SCHULHOFER, supra note 81, at 445-56 (discussing the question of individualization in a section on the "reasonable person requirement" as applied to provocation); KAPLAN ET AL., supra note 62, at 441-45 (same); id. at 635 (discussing how individuated the reasonable person standard should be in the context of self-defense).

${ }^{145}$ For a discussion of mitigation based on disadvantaged background, see David L. Bazelon, The Morality of the Criminal Law, 49 S. CAL. L. REV. 385 (1976); Richard Delgado, "Rotten Social Background": Should the Criminal Law Recognize a Defense of Severe Environmental Deprivation?, 3 LAW \& INEQ. 9 (1985). For a rejection of such a defense, see George Vuoso, Note, Background, Responsibility, and Excuse, 96 YAL.E L.J. 1661, 166162 (1987). On the evolution of various excuses, see Stephen J. Morse, Excusing and the New Excuse Defenses: A Legal and Conceptual Review, 23 CRIME \& JUST. 329 (1998).

14i See Richards, supra note 143 at 464 ("[O]nly ... individualization can assure the basic demand of fairness that normative requirements are framed and applied in ways that persons could reasonably be expected to conform to."). 
approach could lead to abuse. ${ }^{147}$ Critics wanted to locate a set of "bad/abusive" excuses, but offered no clear way to divide the good from the bad. ${ }^{148}$ Had the abuse excuse critics taken their position to its logical end, they would have run headlong into problems with the principle of individualization; for the more the law acquires the characteristics of the defendant, the more the law appears to prefer the defendant to the rest of society.

In the end, the abuse excuse debate punctured the existing consensus but obscured a very different problem with individualization. There is no question but that hyperindividualization may go too far to protect individuals. But it is also true that it may not go far enough to protect individuals. Although intended to be more humane and to sequester the individual from the state, hyperindividualization may backfire, rendering the state invisible-even where it is most obviously oppressive. This is what I call the "paradox of individualization."

To see the paradox, let us begin with Martin $v$. State, ${ }^{149}$ a case in which the defendant was found "drunk in public." We know, however, that Martin did not go out in public on his own but, instead, was dragged out of his house by the police. ${ }^{150}$ The standard pedagogical approach to this case invites discussion of the nature of an individual's voluntary, willed action. ${ }^{151}$ Notice, however, that all of this attention to Martin's personal, individualized ability to act helps to occlude another very important issue: the defendant's relation to the state. Indeed, casebooks try to write the state (the police's conduct) out of the

147 See, e.g., AlAN M. DERSHOWTTZ, THE ABUSE EXCUSE AND OTHER COP-OUTS, SOB STORIES, AND EVASIONS OF RESPONSIBILITY 3 (1994) (calling the abuse excuse a "license to kill and maim"). But see JAMES Q. WILSON, MORAL JUDGMENT: DOES THE ABUSE EXCUSE THREATEN OUR LEGAL SYSTEM? 23-24 (1997) (arguing that public fear of the abuse excuse is overstated, but the law has become too subjective).

${ }^{148}$ See Victoria Nourse, The New Normativity: The Abuse Excuse and the Resurgence of Judgment in the Criminal Latw, 50 STAN. L. REv. 1435, 1441-56 (1998) (book review) (finding the distinction between abusive and legitimate excuses still elusive).

14:) 17 So. 2d 427, 427 (Ala. Ct. App. 1944).

$150 \mathrm{Id}$.

151 See, e.g., KADISH \& SCHULHOFER, supra note 81, at 174-75, 180-81 (asking questions designed to test whether the defendant committed a "voluntary" act); see also Mark Kelman, Interpretive Construction in the Substantive Criminal Lawv, 33 STAN L. REV. 591,592 (1981) (“[I]ssues of the voluntariness of a defendant's conduct can be resolved only after we have agreed, for reasons outside of our rational discourse, to include within the relevant time frame some obviously voluntary act that contributes to the ultimate harm."). 
case by positing a different set of facts. ${ }^{152}$ But, assuming that we are sticking to the actual facts of Martin, one wonders why the police are irrelevant. $^{153}$

The point here is to see that our attention to individualized notions of voluntariness already assumes the state out of the picture. By focusing our attention on voluntariness as a feature of individual conduct (as opposed to the defendant's relation to the state), we have chosen a particular level of analysis. We have chosen to ignore the institutional effects of the case. Put in other words, we have neglected the effect of the case's holding on the institution of punishment. For such an inquiry, the state's relation to the defendant is clearly relevant-if not essential. Put bluntly: would it be legitimate for the state to "create" the crime of "public nudity" by pulling naked people out of their beds and bringing them into the street? The state that "creates" crime is certainly not one that any of us wants and that is why the law has created entrapment rules-not for defendants but for the rest of us.

Once we focus on the defendant's relation to the state, other cases and problems begin to take on a new cast. Consider State v. Norman, a case discussed above about a battered woman who killed her sleeping husband. ${ }^{15 \pi}$ The standard debate about Norman (and indeed about most battered woman self-defense cases) is often characterized as a question of the reasonableness of her views of imminence or perception of harm. This, in turn, yields insistent questions about whether we should apply a subjective or objective standard in selfdefense law, a question focused on individualization. The only problem with all of this is that, just as in Martin, the intellectual focus on the individual tends to divert us from the state's role. The police's ac-

${ }^{152}$ See KaPLAN ET AL., supra note 62, at 137 (suggesting that it should not matter that the defendant was taken out of the house by the police by posing a hypothetical in which the defendant is thrown out by a private party).

${ }^{153}$ One might argue that the relevant "act" was "disturbing the public peace," which occurred only "after" the police dragged the defendant out of the house and that this was an "independent" act and crime. That does not eliminate the state's role in the case-or resolve the entrapment question-since the relevant inquiry would still be whether the police's conduct "caused" the crime. That there is an "act" does not mean that the state may always punish that act; entrapment assumes that a crime has been committed. The ultimate question is whether the state "created" the criminal conduct-and that depends upon a causal determination. See Sorrells v. United States, 287 U.S. 435, 451 (1932) ("The government may not punish an individual "for an alleged offense which is the product of the creative activity of its own officials.").

154 378 S.E.2d 8 (N.C. 1989).

155. Supra text accompanying notes 63-74. 
tions toward Norman were real; they were not simply part of her perception. The police came and insisted that she sign a warrant (a practice not likely to be the case in many states today) and they witnessed a felony threat (to let Norman "die") and yet did nothing. These facts were not and cannot be resigned to Norman's individual consciousness; they did not happen in her mind. They are a matter of state responsibility that, for all of our talk about individualization, tend to be ignored in the standard literature.

Finally, let us turn to the rather well-known case of the Williams family, charged with child neglect and negligent homicide for the death of their baby. ${ }^{15 i}$ Again, this is a case taught in almost every criminal law course in the country and, on the doctrine and the result, is a legitimately hard case. But it is a case that is universally regarded as raising primarily a problem of individualization-questions about how we define the reasonable person and whether that definition should require actual knowledge of a serious risk of death. ${ }^{157}$ The case is thought, with some apparent condescension, to raise the question whether we should define the reasonable person as a Native American or simply a poorly educated person (in other words, like someone other than the students reading the case). The standard question thus presented is about individualization: do we take account of the defendants' background? Their education? The fact that they live on a reservation? ?:58 $^{10}$

As in Martin and Norman, the conventional focus on the characteristics of the Williams defendants tends to occlude the role of the state by embedding it within the mind of the reasonable person. The Williams parents claimed that they did not take their baby to the doctor during the short window of time during which the baby could have been saved ${ }^{159}$ because they were afraid that the authorities would take

${ }_{156}$ State v. Williams, 484 P.2d 1167, 1174 (Wash. Ct. App. 1971).

157 See, e.g., Samuel H. Pillsbury, Crimes of Indifference, 49 RuTGERS L. REv. 105, 195 (1996) (discussing the "individualization dilemma" as "whether the reasonable person personifies a universal standard or whether this fictional construct should be invested with some of the characteristics of the accused"). The question in Williams thus becomes, as Pillsbury puts it, "should the defendants' actions be compared to a person of reasonable prudence, or to a reasonably prudent Native American with less than a full high school education?" $I d$. at $\mathbf{1 9 5}$. Pillsbury recognizes that this inquiry, even if amended by H.L.A. Hart's capacity test, "misses a vital issue: the affirmative reason for the Williamses' inaction." Id. at 197.

${ }^{158}$ Id . at 195.

159 There was a five-day window of opportunity in which, had they taken the baby to the doctor, he could have been helped. Defendants believed that the child was suffering from a simple toothache and they administered aspirin to address the problem. 
their baby away. ${ }^{160}$ When one first encounters this defense, it sounds like a desperate plea of otherwise rather selfish parents. It was not, however, that the Williamses were ignorant. To the contrary, the Williamses were scared-and they had good reasons to be scared. During this period, perhaps as many as one-third of Indian children were taken away from their parents by state authorities. ${ }^{161}$ Congress ultimately acknowledged these practices, including the assumption of some social workers that living on an Indian reservation was not a "proper place" for a child to grow up. ${ }^{162}$ One need not conclude from this that the Williams parents were above reproach or that their actions

In fact, the tooth would become infected and gangrenous, accounting for the "bluish" color on the cheek. See Williams, 484 P.2d at 1174 ("Accordingly, the baby's apparent condition between September 1 and September 5, 1968 became the critical period for the purpose of determining whether in the exercise of ordinary caution defendants should have provided medical care for the minor child.").

${ }_{160}$ Defendant husband testified that "the way the cheek looked, ... and that stuff on his hair, they would think we were neglecting him and take him away from us and not give him back." Defendant wife testified that the defendants were "waiting for the swelling to go down," and also that they were afraid to take the child to a doctor for fear that the doctor would report them to the welfare department, who, in turn, would take the child away. "It's just that I was so scared of losing him." They testified that they had heard that the defendant husband's cousin lost a child that way.

Id. at 1174 .

${ }^{101}$ Surveys of States with large Indian populations conducted by the Association on American Indian Affairs (AAIA) in 1969 and again in 1974 indicate that approximately 25-35 percent of all Indian children are separated from their families and placed in foster homes, adoptive homes, or institutions ... . The disparity in placement rates for Indian[s] and non-Indians is shocking .... In the State of Washington, the Indian adoption rate is 19 times greater and the foster care rate 10 times greater [than for non-Indians, i.e. Indian children are much more likely to be taken from their families than other children.]

William Byler, Removing Children: The Destmation of American Indian Families, C.R. DIG., Summer 1977, at 19, 19. Moreover, Indians are usually placed with non-Indian foster care or adoptive families. See id. at 20 (noting a survey of sixteen states that found that approximately " 85 percent of all Indian children in foster homes were living in nonIndian homes").

${ }_{162}$ In judging the fitness of a particular family, many social workers, ignorant of Indian cultural values and social norms ... frequently discover neglect or abandonment where none exists. For example, the dynamics of Indian extended families are largely misunderstood. An Indian child may have scores of, perhaps more than a hundred, relatives who are counted as close, responsible members of the family. Many social workers ... consider leaving the child with persons outside the nuclear family as neglect and thus as grounds for terminating parental rights.

$I d$. at 20 . In one case, "social workers asserted that, although they had no evidence that the mother was unfit, it was their belief that an Indian reservation is an unsuitable environment for a child." Id. at 22. 
should not be condemned. After all, the child's life must come before the parents' relation to the child. Yet the state's conduct is unsettling in a way similar to that in Martin - the state appears to be prosecuting defendants for a situation that the state itself may have helped to create. $^{1 ; i 3}$ At the very least, it seems relevant to ask-although the question is rarely raised-why the state prosecuted these parents.

The principle of individualization helps to occlude these questions by placing facts about the state and the defendant's relation to the state within the minds of the defendants themselves—and then asks whether these are the minds of "reasonable persons." only place where these facts belong? Is it really a "liberal" theory of the criminal law that asks us whether these people are "like us"? Isn't there a real problem here in that the state was taking away babies because they thought these parents "lesser" in some way? My point is not that these facts exonerate, but that they raise important questions about something more than how we "describe" the Williamses' individual minds, psychology, or background. One need not go further than the entrapment defense to recognize that a just relation between a citizen and state may require that the state acknowledge its own participation in crime and that such participation recommends leniency or mitigation. ${ }^{\text {liti }}$

Indeed, what becomes clear by the time we take a look at Williams is how, in a world where we focus on describing defendants, we can end up with a description that actually deforms individuality. In Martin, Norman, and Williams, the state is quite literally put into the defendant's mind or body. We are taught, and continue to teach, that it is the defendant's perceptions or actions that are central to these cases and that it is only through the defendant's characteristics or character that the state's actions are comprehended. We ask, for example, whether the Williamses' or Norman's perceptions of the situation

11:3 My claim should not be read as a call for" a "the state made me do it" defense (beyond where entrapment law would already apply). I do think, however, that there are grounds for questioning why these prosecutions were brought and that such questions are quite important.

lit The child neglect statute in Williams required "willful" neglect, a point often omitted from casebook reprints. The Williamses' lawyer certainly would have wanted to argue that the defendants were hardly willful, where that means defiant of community norms; they were simply afraid. On defiance and mens rea, see Hampton, supra note 135 , at 1 .

${ }^{105}$ Cf. Jacobson v. United States, 503 U.S. 540, 553-54 (1992) ("When the [g]overnment's quest for convictions leads to the apprehension of an otherwise lawabiding citizen who, if left to his own devices, likely would have never run afoul of the law, the courts should intervene."). 
were reasonable, not whether the state's relation to these defendants merited a prosecution. We ask whether Martin's actions were in fact voluntary, willed bodily movements, not whether the state's relation to him caused the criminal act. The state's actions thus become a feature or a characteristic of individuality. Can there be a greater perversion of the notion of individualization than the idea that the state has become embedded in the defendant's mind or body?

The potential paradox of individualization may now be stated in its most extreme form. Protecting defendants is not the same as describing them; protecting them means enforcing a just relation between the state and the defendant. Currently, our only option in a crudely descriptive, hyperindividualistic world appears to be to pathologize defendants, to render them sick, insane, or somehow subject to special rules for special classes. The poor town drunk, poor battered woman, and the poor ill-educated Native American: they are sick and all good liberals should have compassion. But this kind of condescension, however wrapped up in kindness, risks blindness to oppressive relations. ${ }^{\text {liii }}$ The problem with individualization is not simply that some excuses may be abused; the problem with individualization is that it may not be enough to protect individuals from a world of real inequality and bias-inequality and bias that do not exist simply in the minds or bodies of defendants.

I have no quarrel with the notion that individualization is necessary; my quarrel is with the idea that it is sufficient. Individualization leaves many questions simply unanswered and unanswerable. How many times are we to be asked about "which characteristics count" for the reasonable person in provocation, negligence, and self-defense cases when we have long known that such a question cannot be answered?"1iz At least some of the time when we ask the "character or characteristics" question, we do so because we smell a rat; we sense that there is a problem in the case. The problem, though, as we have seen, may not be about an individual but instead about his relation to others or the state (it may be about the police pulling someone out of a house, taking away children, or failing to arrest).

liti See, e.g., MACKINNON, supra note 73, at 243 (decrying antifeminism as a "systematic relegation of an entire people to a condition of inferiority ... attributed to them, made a feature of theirs ...,").

${ }^{11 i 7}$ See, e.g., MOdEL PENAL CODE $\$ 210.3 \mathrm{cmt} .5$ at $62-63$ (1980) (explaining that the Code's reference, in provocation cases, to the reasonable person in the actor's "situation" is "designedly ambiguous" and arguing that the proper factors or characteristics for assessing the "reasonable person" in the "situation" cannot be "resolved satisfactorily by abstract definition"). 
There are obvious costs to such an intellectual strategy: once the state's actions are embedded within the defendant's mind, questions of state-imposed inequalities simply disappear. Thus, if we think that the only real question in Martin is "willed bodily movement," we will not ask why the police picked him, of all people. If we think the only real question in Norman is her "perception" of the situation, her "syndrome," or her failure to respond to an "imminent" threat, we will pay no attention to the police officer's reasons for failing to arrest. If we think that the only real question in Williams is whether the defendants' education should "count" as a characteristic, then we will not ask why the state prosecuted at all. In a world in which individualization alone is the only question one thinks necessary to ask, then one is committed to embedding questions about inequality into the minds and bodies of defendants.

\section{B. Traditional Political Theory and the Criminal Law}

If this theory is right, then it should quiet those who believe that, by invoking the name of the state, or the relation of the defendant to the state, I have undermined the cause of individuals or their rights. I mean no such thing. I mean, instead, to add to the ways in which we may begin to think about protecting individuality. Thinking in new ways, however, is difficult. And there will be those who will be tempted to insist that my emphasis on relation "adds" a political theory to the criminal law or encourages an anti-individualistic illiberalism. My response is that $I$ have added nothing that cannot be found in rather traditional liberal political theory. Thus, whether or not one adopts such a theory, it seems difficult to conclude that a focus on the defendant's relation to the state is, by itself, illiberal.

For some, the very idea of invoking the state may offend. For them, the very term "state" may sound so oppressive as to obliterate the individual. My answer is to express urgent agreement and disagreement simultaneously. Yes, the state may be oppressive, and, yes, the merger of the individual into the state is the very definition of tyranny. Indeed, this was the hallmark of twentieth-century totalitarian political philosophy. ${ }^{\text {lis }}$ But what I am urging is precisely the opposite of

${ }^{1 \text { tix }}$ For example, Hannah Arendt discusses how "total terror," which she views as the essence of totalitarian government, "press[es] men against each other ... [and] destroys the space between them." HANNAH ARENDT, THE ORIGINS OF TOTALTTARIANISM 466 (new ed. 1973). By destroying this space, tyranny eliminates both the individuality of the subject and the space of freedom between the subject and the state. $I d$. 
such a merger. It is not the eradication of a healthy relation between citizen and state, but instead, attention to that relation. I do not want to close what Hannah Arendt called the space between individuals, or between them and the state. ${ }^{16 !}$ I want to keep that space; I simply want to make it clear that we are arguing less about an empty space than a dynamic, human relation.

That I have called this space a "relation" may raise different kinds of fears. For some, it will be the fear that I am trying to smuggle something frighteningly "feminist" into the criminal law without avowing it. And, yes, there is a sense in which the word "relational" might connote a particular kind of cultural feminism. ${ }^{170}$ But that is not the sense in which I am using the term here. For those afraid of the idea of "relation," it is important to remember that the notion of a relation is, in law, at least as traditional as Hohfeld, Black, and Macaulay. ${ }^{171}$ And, contrary to conventional wisdom, there is plenty of traditional liberal political philosophy that depends upon a just relation between individual and state. Open Montesquieu's The Spirit of the Laws and you will find immediate reference to laws as "necessary relations." 172 Indeed, the focus of much of The Spirit of the Laws is on the relations between "the governors and the governed" (laws of political right) and those between "members of society . . . as they stand in relation to each other" (laws of civil right). ${ }^{173}$ These, of course, are the very relations we have seen above. ${ }^{174}$

109 Id.

170 The work of Robin West and Mary Becker is often associated with "relational" feminism. On the question of the meaning of relational feminism, see Symposium, Feminist Theories of Relation in the Shadow of the Lam, 17 WIS. WOMEN'S L.J. 1 (2002). For good examples of the debate on the consequences and meaning of relational feminism within political theory, compare Jennifer Nedelsky, Violence Against Women: Challenges to the Liberal State and Relational Feminism, in POLITICAL ORDER: NOMOS XXXVIII 454 (Ian Shapiro \& Russell Hardin eds., 1996), with Robert Goodin, Structures of Political Order: The Relational Feminist Altematives, in POLITICAL ORDER: NOMOS XXXVIII, sufra, at 498.

${ }_{171}$ See BLACK, supra note 43 (using relations between governmental structures to describe our Constitution); Wesley Newcomb Hohfeld, Some Fundamental Legal Conceftions as Applied in Judicial Reasoning, 23 YALE L.J. 16 (1913) (disaggregating rights into an elaborate set of relations of opposites and correlatives); Stewart Macaulay, NonContractual Relations in Business: A Preliminary Study, 28 AM. SOC. REv. 55 (1963) (studying the ways in which long-term relationships affect our understanding of real-life contracting).

172 "Laws, in their most general signification, are the necessary relations arising from the nature of things." MONTESQUIEU, supra note 27, at 1 .

${ }^{173}$ Id. at 5 . After discussing the various relations of laws to the people, Montesquieu concludes: 
There are those who will continue to insist that I have given up the great liberal concern for the individual by equating structural concerns with the lonely individual. But this step, I will insist, is far from my creation. Violence poses some of the most fundamental questions of liberal political theory and has, for two centuries, stood as the centerpiece of theorizing about the state. Open up your Locke again, if you do not care to focus on Montesquieu, and what do you find? Locke begins The Second Treatise of Government with the problem of violence, emphasizing the ways in which violence may corrupt a polity that aims toward equality and self-government. ${ }^{175}$ A state of nature is one, he tells his reader, of perfect equality, in which there is no aristocracy or monarchy, in which man is "born to all the same advantages of nature," subject to no "subordination or subjection." 176 It is violence that yields subordination: "[T] here cannot be supposed any such subordination among us, that may authorize us to destroy another, as if we were made for one anothers uses as the inferior ranks of creatures are for ours." of war," dependency, and even slavery. ${ }^{178}$

This is what $I$ have undertaken to perform in the following work. These relations I shall examine, since all these together constitute what I call the Spirit of the Laws.

I have not separated the political from the civil institutions, as I do not pretend to treat of laws, but of their spirit; and as this spirit consists in the various relations which the laws may bear to different objects, it is not so much my business to follow the natural order of laws as that of these relations and objects.

Id. at 7 .

${ }^{174}$ Locke also conceives of laws and reason as, in essence, "ties" between men. See, e.g., LOCKE, supra note 56, at ch. 3, para. 16 ("[B] ecause such men are not under the ties of the common law of reason, [they] have no other rule, but that of force and violence....").

${ }^{175}$ See id. at ch. 2 (describing violence and the state of nature).

${ }^{176}$ Id. at ch. 2, para. 4. Locke writes:

A state also of equality, wherein all the power and jurisdiction is reciprocal, no one having more than another; there being nothing more evident than that creatures of the same species and rank, promiscuously bom to all the same advantages of nature and the use of the same faculties, should also be equal one amongst another without subordination or subjection ....

Id.; see also id. at ch. 2, para. 6 (" $[\mathrm{A}]$ nd reason, which is that law, teaches all mankind, who will but consult it that, being all equal and independent, no one ought to harm another in his life, health, liberty, or possessions.").

${ }^{177}$ Id. at ch. 2, para. 6 .

${ }^{178}$ This, in the end, is the argument Locke makes against monarchy. The monarch who

attempts to get another man into his absolute power, does thereby put himself into a state of war with him .... [H] who would get me into his power with- 
Very quickly, the problem of violence poses structural risk. ${ }^{179}$ Locke tells us that: "[I]n transgressing the law of nature, the Offender declares himself to live by another rule than that of reason .... $[\mathrm{H}]$ e becomes dangerous to Mankind," not only because he has broken the idea of natural equality, but also "the tie [to others], which is to secure them from injury and violence." ${ }^{180}$ But this risk of legislation is not the only risk, nor is it the most serious-there is also the risk of execution. To protect themselves, men in the state of nature may "punish the transgressors of that law to such a degree as may hinder its violation." "[S] elf-love will make men partial to themselves and their friends, ... [and] ill nature, passion, and revenge will carry them too far in punishing others."

The implicit equation here between violence, governance and inequality is not unique to the work of Locke; indeed, the equation

out my consent would use me as he pleased ... and destroy me, too, when he had a fancy to it; for nobody can desire to have me in his absolute power, unless it be to compel me by force to that which is against the right of my freedom, i.e. make me a slave.

Id. at ch. 3, para. 17 .

179) Locke describes the state of war that proceeds from violence:

To be free from such force is the only security of my preservation; and reason bids me look on him as an enemy to my preservation who would take away that freedom which is the fence to it; so that he who makes an allempt to enslave me thereby puts himself into a state of war with me. He that, in the state of nature, would take away the freedom that belongs to any one in that state must necessarily be supposed to have a design to take away everything else, that freedom being the foundation of all the rest; as he that, in the state of society, would take away the freedom belonging to those of that society or commonwealth must be supposed to design to take away from them everything else, and so be looked on as in a state of wrar:

Id.

180 Id. at ch. 2, para. 8; see also id. at ch. 3, para. 16 ("[S] uch men are not under the ties of the common law of reason, have no other rule, but that of force and violence."). In this view Locke was not alone. Hobbes took the even more insistent stance that the offender expressed "contempt" of the legislator and thus breached "all his laws at once." See HOBBES, supra note 26, at ch. XXVII, para. I "A [s]in is not only a transgression of a law, but also any contempt of the legislator. For such contempt is a breach of all his laws at once."); see also id. at ch. 27, para. 33 (arguing that the premeditated offender "cast[s] his eye upon the law" and therefore reveals, in his intent, "contempt" for the law).

${ }^{181}$ LOCKE, supra note 56, at ch. 2, para. 7.

${ }^{182}$ Id. at ch. 3, para. 13. This objection is put in the mouth of another, but Locke readily accedes to an imagined objector's proposition that civil government is necessary "to restrain the partiality and violence of men." But he adds that it is important not to repeat the evil in government itself by relying upon an absolute monarch who, too, will be the "judge in his own case," doing to his "subjects whatever he pleases," and "[e]xecut[ing at] his pleasure." I $d$. 
rests on a principle that Stephen Holmes has called the "strong norm at the heart of liberal morality: the self-exemption prohibition., ${ }^{18: 3}$ In civil society, neither state nor man (including the king) "can be exempted from the laws of [civil society]," said Locke, ${ }^{184}$ and, in this, his views were shared by a variety of otherwise differently-positioned liberal thinkers, including Blackstone and Montesquieu, Beccaria and Smith. ${ }^{185}$ What makes a monarch into a tyrant but his imposition of the law on others while exempting himself, making himself "better" than those whom he rules? What makes an individual offender into one who subordinates another but his exemption of himself from the rules of nonviolent interactions by the use of force, making himself dominant over those he harms?

The risk of self-exemption poses an extraordinarily serious problem for any liberal theory of the state. If there are no restraints on the individual use of violence, then liberalism is impossible because the strong will rule over the weak. But if one institutes government to control individual violence, one must control not only those being governed but also those governing from, again, instituting a rule of the strong. Without controlling the latter, one has replaced one form of aristocracy of the strong with another.

If this is right, then we can return to the basic premise with which I began this Article and hear the modern vernacular in its more ancient context. Listen to the angry debates about some of the most controversial criminal law cases. Hear critics of Bernhard Goetz cry that he "took the law into his own hands."

${ }^{183}$ HOLMES, supra note 25 , at 238. 238.

${ }^{184}$ LOCKE, supra note 56, at ch. 7, para. 94, quoted in HOLMEs, supra note 25, at

1\$. "[I]n republics private crimes... [run counter to] the constitution [of the state] more than [against] individuals; and, in monarchies, public crimes are more private, that is, they" run counter to individual fortunes more than against the constitution of the state. MONTESQUiEU, supra note 27, at bk. III, ch. 5. One cannot inflict great punishments, and consequently, make great changes, without putting a great power into the hands of a few citizens. On the pretext of avenging the republic, one could establish the tyranny of the avengers. Id. at bk. XII, ch. 18; see also HOLMES, supra note 25, at 238-39 (discussing Beccaria, Montesquieu, Blackstone, Smith, and the anti-self-exemption principle).

${ }^{186 \mathrm{i}}$ Jay Maeder, Quality of Life: The Subway Vigilante, N.Y. DAILY NEWS, Nov. 8, 2001, at 79; see also A Goetz Trial Again, WASH. TıMES, Apr. 10, 1996, at A16 ("When Bernie Goetz ... took the law into his hands on Dec. 22, 1984, a lot of law-abiding citizens ... were absolutely prepared to believe he'd acted in self-defense when he shot them. And a jury agreed. Mr. Goetz was acquitted of assault and attempted murder in 1987."). 
Judy Norman who claims she became "judge and executioner."187 These are not isolated phrases. They punctuate law review articles and news accounts; they appear on television newscasts and in legal treatises, asserted by both scholars and pundits alike. ${ }^{188}$ Now look closer. Goetz is accused not of an individual failing-of lacking selfcontrol, making bad choices, or having a bad character-but rather, he is accused of being a "lawmaker." Similarly, Norman is not being accused of individual failings such as psychological trauma or even failed virtue but, instead, she is accused of being an "executioner." These are structural sins, not individual ones. This should be less of a surprise. For, to see in violence risks to governance and governing structures is to silently invoke a rather ancient tradition in liberal political philosophy.

\section{IMPLICATIONS}

At this point, having countered the most obvious objections, it is worthwhile turning to the theory's implications. How does criminal law and theory change if we accept my premise that it has constructive and political import-that we cannot simply look at the content of the prohibition alone, but must consider its effects on majorities and governance as well? In this concluding section, I present but a sketch of the possibilities.

\section{A. New Questions for Doctrine and Study}

If I am right, then we have a new set of collateral effects questions to ask about the standard doctrines of the substantive criminal law. We may put to the side, at least for the purposes of inquiry, the questions typically asked about whether a particular criminal rule or doctrine serves the "purposes" of retribution or deterrence. Such questions, after all, assume that we can corral these concepts within manageable terms and, perhaps more importantly, that they are the only possible "purposes" one might posit for a criminal law. ${ }^{189}$ If the

187

See Fletcher, supra note 67 , at 556 (“[H]owever tragically Judy Norman's appeals to the authorities went unheeded, she cannot put herself in the position of judge and executioner.").

${ }^{188}$ Scholars definitely are not immune from this tendency. Id. at 553; see also Sanford H. Kadish, Fifty Years of Criminal Law: An Opinionated Review, 87 CAL. L. REV. 943,967 (1999) (noting that there was a reluctance to embrace a necessity defense lest it "encourage people to take the law into their own hands").

${ }^{1899}$ Nietzsche exploded this idea by outlining an exceedingly long list of the possible "purposes" of punishment. FRIEDRICH NIETTSCHE, THE GENEALOGY OF MORALS: 
criminal law serves to create public order-if it governs-then presumably there are other "public law" questions to be asked. And, as I have argued above, those questions may well provide us with new perspective. For, as we have seen, in such a world, questions of insanity may become ones of citizenship and questions of necessity may become ones of legislative tyranny.

We need not exclude the old questions, of course, but in asking these new ones, we may gain perspective on some rather persistent problems. The great irony here is that, although these questions have a "public" and institutional aspect, this kind of inquiry may actually help to depoliticize various debates (where "politicize" is used in its more colloquial sense of being unprincipled or ad hoc). Today, public and even scholarly debates about the criminal law tend to be arrayed on a spectrum of how one feels about defendants-whether one believes defendants are likely to be oppressed (a liberal pro-defendant position) or whether one believes that they are likely to be oppressors (a conservative pro-victim posture). The truth, of course, is that this is far too crude a calculus; indeed, it is nothing more than a set of prejudices. Any realistic approach toward the criminal law must consider not only the demands of those likely to be victimized, but also accused victimizers and their relation to each other. We cannot achieve such perspective, however, if we imagine that justice depends upon maintaining these questions in isolation.

Finally, and it is important to emphasize this, recognizing the public law aspects of the criminal law does not mean capitulating to what lawyers somewhat derisively call "politics." Indeed, it requires us to imagine not only public permissions, but also public limits. To take a simple example, debates about criminalization have often centered around the question of whether the law should preferentially protect individuals or society. ${ }^{1: m}$ But note what these conventional positions share: the idea that one must choose between two discrete and disconnected alternatives-the individual on the one side and society on the other. A collateral effects theory of the criminal law makes no such assumption but considers the possibility that there is a false dichotomy

Ploples ANd Countries 92-95 (Horace B. Samuel trans., Oscar Levy ed., 1964) (1887).

Consider, for example, the Hart-Devlin debate concerning whether individual or social harm should be the measure of a crime. For a recent account of the debate, see Bernard E. Harcourt, Criminal Law: The Collapse of the Harm Principle, $90 \mathrm{~J}$. CRIM. L. \& CRIMINOLOGY 109 (1999). 
in play. ${ }^{191}$ To take a contemporary example, a perspective that focuses on political effect does not ask whether sodomy laws would harm individuals or violate social norms. ${ }^{192}$ Instead, it asks what kind of public order such laws help to construct. Such an approach considers not only whether sodomy laws express contempt for particular persons' sexual orientation, but also whether they contribute to a political order of heterosexual supremacy-by enlisting government violence in the enforcement of sexual inequality.

\section{B. Explaining Confounding Theoretical Developments}

If this analysis raises new questions for doctrinal practice, it also raises new questions for substantive criminal law theory. In particular, it helps to make sense of three recent theoretical developments that, from the hyperindividualist perspective, appear to be rather disturbing, or at least anomalous: the rise of feminism, the decline of the harm principle, and the emergence of social norms in the literature of the substantive criminal law.

It has come as something of a surprise to traditionally-educated academics that, of all the developments in legal scholarship in the past twenty years, feminism has had such an impact on the substantive criminal law. ${ }^{193}$ Indeed, some have suggested, somewhat derisively, that the impact of feminism has been "political," where "political" is meant to operate as a synonym for "partial" or "unprincipled." If I am right, however, there is a theoretical framework which predicts this development: feminists take the view that the criminal law has, embedded within it, rules that help to constitute a gendered political order. Hostility to feminism's challenges to the criminal law, in this sense, reflects no hostility to women, but a resistance to the public dimensions of feminism. It is only if one assumes that the political

${ }^{191}$ In this sense, this project takes its inspiration (albeit not its doctrinal subject matter) from the law and society movement which was, originally, dubbed law in society to avoid such a dichotomizing move. See William N. Eskridge, Jr., In Mernoriam: Willard Hurst, Master of the Legal Process, 1997 WISC. L. REV. 1181, 1183 (describing the earliest class on public lawmaking and noting that the teaching materials were entitled Law in Society).

192 This example is the problem that inspired the Hart-Devlin debate. See Harcourt, supra note 190, at 118-20 (introducing the origin and historical transformation of the Hart-Devlin debate).

${ }^{193}$ See Fletcher, supra note 28, at 279 ("The only academic movement of the $1980 \mathrm{~s}$ that made an impact on criminal law was feminism."); Kadish, supra note 188, at 974 ("Feminism ... is the one major movement of the period that has had a significant impact on the shape of the criminal law."). 
order should have nothing to do with the criminal law that feminism's claims about a public gendered order may be deemed self-evidently political where the term "political" is a synonym for "unprincipled."

A similar analysis helps to explain the fears elicited, under traditional theory, by the collapse of the "harm" principle. The HartDevlin debate seemed to place "harm to individuals" at the center of scholarship about liberalism and the criminal law. As Bernard Harcourt rightly insisted, however, the "harm" principle has appeared to unravel in the latter half of the twentieth century. ${ }^{194}$ From a traditional, individualist view, of course, this should seem very troubling indeed; the harm principle has been considered one of the most basic limits on the exercise of criminal law jurisdiction. ${ }^{1 ! 5}$ But if political norms play a decided role in creating the criminal law, one should hardly find their role in determining "harms" unusual; indeed, one would expect that majoritarian norms would seek to define and redefine "harm" in their own image. What Harcourt, along with many traditional scholars, is worried about is the risk that majoritarian norms may be biased and thus may covertly punish based on status or race or some other prejudicial reason. Return, for example, to the criminal law's treatment of sodomy. The real problem with sodomy statutes is not that they cannot be found to address someone's odd sense of harm, but, rather, that they are "code" for the oppression of persons based on sexual orientation. That, in turn, is not only a problem for individuals but for the notion of a liberal order as well. By using violence to enforce sexual inequality and heterosexist superiority, the state taints its own claims to democratic legitimacy. ${ }^{196}$

194

See Harcourt, supra note 190 , at 113 (“[T] he harm principle is effectively collapsing under the weight of its own success. Claims of harm have become so pervasive that the harm principle has become meaningless ....").

${ }^{195}$ See id. (suggesting that the collapse of the harm principle means the loss of a "critical principle" limiting the scope of the criminal law, and marking a "radical departure from the liberal theoretic, progressive discourse of the 1960s"); id. at 115-16 (contending that the liberal philosophical consensus is that harm is required to punish, but that this "liberal" position, taken by H.L.A. Hart, Joel Feinberg, and Ronald Dworkin, has been "colonized by conservatives").

${ }^{1953}$ As one may glean from this discussion, I am sympathetic to the recent call by Bill Stuntz for greater consideration of the ways in which governmental structure has an influence on the criminal law. See William J. Stuntz, The Palhological Politics of Criminal Latw, 100 MICH. L. Rev. 505, 587-600 (2001) (suggesting that courts should have more power to craft criminal law because they will balance out the power of legislatures and prosecutors to "define crimes as they wish"). Indeed, I believe that this "public law" approach may help to provide the background theory for those interested in the quest, at the doctrinal level, to constitutionalize basic rules of substantive criminal law. Traditionally, the arguments that courts and commentators have used to constitu- 
Finally, "public law" questions help to secure a strong place in the criminal law for social norms. In the past ten years or so, criminal law scholarship has moved rapidly toward a growing consensus that social norms are strong influences on the enforcement and the meaning of the criminal law. ${ }^{197}$ This, of course, has come as something of a shock to the hyperindividualist, resistant as she is to any shift in focus toward society. And yet, from a "public law" perspective, this move toward norms seems not only advisable but essential-even if it remains incomplete. As even its strongest adherents suggest, once one comes to view social norms as upwardly mobile within the criminal law, one must confront the fact that sometimes these norms reflect disdain, cultural prejudice, or general ugliness. There is no question, of course, that throughout our history the criminal law has been used as a means to express contempt for others. That this is an inevitable and nasty part of democratic politics is to be bemoaned. But it seems easier, to me, to try to counter such hubris if one recognizes that it is a political order that is at stake. That social norms play a role in the criminal law does not mean that they must always and in every form be allowed to control the criminal law.

\section{The Relation Between Substance and Procedure}

If the substantive criminal law is to come out of the shadow of its bell-bottom years, if it is to move beyond the twentieth century's obsession with defendants' psyches and personality characteristics, then we must be wise enough to begin to challenge the "givens" of the construction of the very subject matter of the criminal law. First, we must consider two important aspects of the traditional canon: the conventional split between the substance of criminal law and the procedure of criminal cases, and the deliberate isolation from public law that has characterized criminal law scholarship.

It is not only at the doctrinal level that we have seen the criminal law imagine individuals isolated from the state; the public/private split can be seen as well in the very construction of the "subject matter" of the criminal law. It is conventional, for example, to teach a certain set of doctrines in the substantive criminal law, leaving all mat-

tionalize certain practices or rules in the criminal law have invariably focused on individuals or on procedures. A collateral effects approach suggests that the proper form of the argument may be structural.

1:77 See Dan M. Kahan, What Do Alternative Sanctions Mean?, 63 U. .CHI. L. REv. 591, 592-94 (1996) (suggesting that by examining social norms society might be able to identify meaningful alternative forms of punishment). 
ters having to do with the "state" to criminal procedure. Substantive criminal law teachers thus prefer to teach about Martin" $^{198}$ as a case about willed bodily movements or about Norman ${ }^{193}$ as one of syndromes or about Hinckley ${ }^{200}$ as about mental illness. But, relegating the state to the "procedural realm" at the outset may well blind us to important questions about the relation of the state to individualsabout who took Martin out of the house (the police) or why Norman did not seek help (state refusal to assist). Indeed, by severing criminal procedure from the substantive criminal law, we have severed the criminal law from its rather obvious connections to the creation of a liberal polity, only reinforcing the assumptions with which we began (the disconnect between individual and society).

This realization may be particularly important in an era where there are many reasons to believe that courts are unlikely to grant new procedural rights. As courts-particularly federal courts-become institutions with shrinking capacity, ${ }^{201}$ a public law approach suggests that we will be faced with increasing risks to governmental structure (effected by means of the criminal law). What I mean by this is that if rights have institutional implications, implications for the protection of us all, then as rights decline in power and scope we can expect to see larger and larger pockets of "inadvertent aristocracy" in this country. For example, consider that there are currently places in America where minorities remain unrepresented precisely because of the criminal law. Go into the poor, urban, minority neighborhoods of this nation and try to round up voters and you will find vast numbers of people disenfranchised by the rule that felons cannot vote. In a world where rights and structure are imagined and maintained as separate intellectual projects, such conditions may well be rendered invisible or disregarded.

Criminal law teachers have not always been loathe to talk about the criminal law and the demands of a liberal polity. Once upon a time, it was perfectly appropriate for a scholar to talk of the criminal law as "an instrument of the state."

198 Martin v. State, 17 So. 2d 427 (Ala. Ct. App. 1944).

$1: 99$ State v. Norman, 378 S.E.2d 8 (N.C. 1989).

${ }^{210}$ See supra notes 120-24 and accompanying text (discussing the Hinckley case).

201 See NEIL K. KOMESAR, LAW'S Limits: THE ROLE OF LAW AND THE SUPPLy AND DEMAND OF RIGHTS 185 (2001) (arguing that in an increasingly complex and globalized world the "tiny adjudicative process" will be in increasing demand and will not be able to grow as fast as alternative institutions like the political process and the market).

${ }^{202}$ MICHALL \& ADLER, supra note 1, at 342-43. 
Mortimer Adler could write openly about how the criminal law served the modern liberal state, ${ }^{203}$ but this kind of intellectual focus has long since been omitted from the pages of the law reviews. In part, this result was motivated by historical events, most notably totalitarian abuses of the criminal law both before and after World War II. The lesson taken from this historical experience was that the criminal law must protect individuality at all costs. But, as I have tried to show here (with the "paradox of individuality"), focusing our efforts on individualization may be necessary but is not sufficient to ensure the justice of the criminal law.

In the end, a public law perspective beckons to those scholars who have an interest or a background in disciplines that may help to put the criminal law's commitments in public perspective. It is the study of history and political structure that brought me, for example, to some of the insights gained here. It is from that study, along with the study of comparative criminal law, that we may gain greater insight into how criminal law governs. One might profitably, it seems to me, engage in comparative, empirical studies of how changes in criminal law affect or reflect changes in political structure. Similarly, one might achieve a similar sort of perspective from a study of the historical development of various doctrines or theories, to illuminate how the law came to evolve in directions that reflected changing conceptions of political or cultural order. History, political theory, and comparative law are all likely to be essential in this ongoing project. But such an account is not even possible in a world where criminal law is public law in name only.

\section{CONCLUSION}

The criminal law not only punishes individuals but governs us all. If this is right, then it should seem odder that criminal law scholarship has generally sought to avoid "the political." If, indeed, the criminal law is viewed as a means of governance, then it is both more important than it is generally believed to be and less arcane than we might have

203 See, e.g., id. at 342 ("[T] he criminal law like any other body of law having a political sanction, is an instrument of the state. It is designed and administered for the sake of the welfare of a political society, however much in fact it may serve contrary purposes."). The authors continue: "[B]ehavior ... is determined to be undesirable by reference to the constitution of a particular political society. Since states differ in their constitutions and since their constitutions determine their welfare differently, behavior which is contrary to the welfare of one state may not be so considered in another." Id. at 354 . 
otherwise thought. It is more important because it serves as the very foundation for any constitutional order. It is less arcane and specialized because it becomes a fundamental branch of a more generalized vision of public law.

I recognize that this is not at all how the criminal law is taught or understood today. The traditional view tries to keep ideas of political theory at bay, either going above the state (to morality) or below it (to individuals). I have struggled with this Article in large part as an attempt to bring the criminal law back within the public law academy to show how debates about representation, citizenship, and majoritarianism might have something to do with the criminal law even in the last place that one might look-in the criminal law's most particular and defensive doctrines. 